\title{
Managing coastal environments under climate change: Pathways to adaptation
}

\author{
Agustín Sánchez-Arcilla ${ }^{\text {a,b }}$, Manuel García-León a , Vicente Gracia ${ }^{\mathrm{a}, *}$, Robert Devoy ${ }^{\mathrm{c}}$, \\ Adrian Stanica ${ }^{\mathrm{d}}$, Jeremy Gault ${ }^{\mathrm{c}}$ \\ a Laboratori d'Enginyeria Marítima, Universitat Politècnica de Catalunya, C/ Jordi Girona, 1-3 Ed. D1 Campus Nord, 08034 Barcelona, Spain \\ b Jordi Girona, 1-3, Ed. D1, 08031 Barcelona, Spain \\ c MaREI Centre, Environmental Research Institute, University College Cork, Ringaskiddy, Co. Cork, Ireland \\ d Natl. Institute of Marine Geology and GeoEcology - GeoEcoMar, Str. Dimitrie Onciul 23-25, Sector 2, 024053 Bucharest, Romania
}

\section{H I G H L I G H T S}

- It is addressed how to sustainably manage coastal systems under changing climates.

- Adaptation for long-term trends and short-term events is analysed through DPSIR.

- Physical and socio-economic pressures are included.

- High and low sustainability practices are analysed.

- It focuses on a sequence of interventions that enhances the natural resilience.

\section{G R A P H I C A L A B S T R A C T}

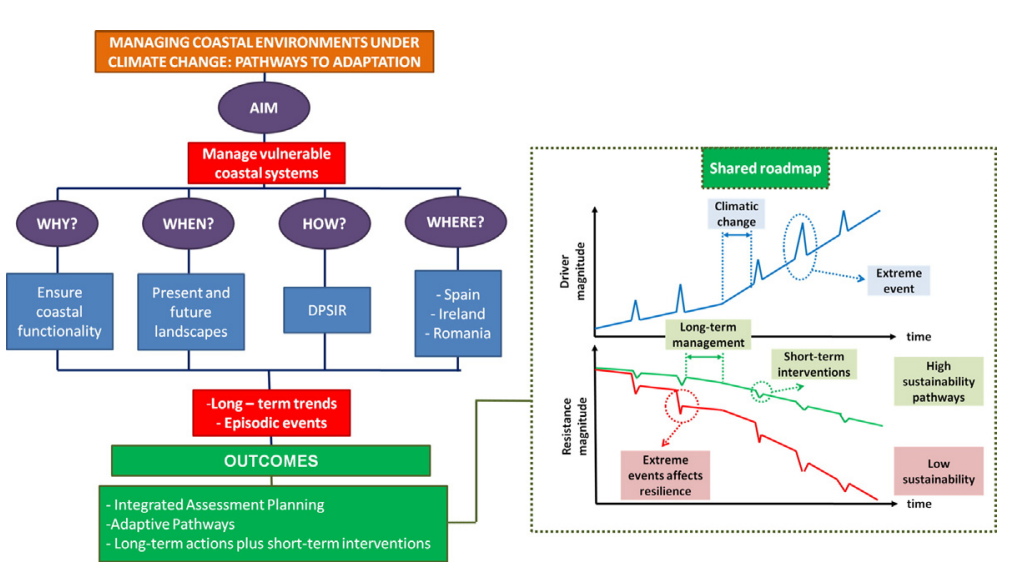

\begin{abstract}
A B S T R A C T
This paper deals with the question of how to manage vulnerable coastal systems so as to make them sustainable under present and future climates. This is interpreted in terms of the coastal functionality, mainly natural services and support for socio-economic activities. From here we discuss how to adapt for long term trends and for short terms episodic events using the DPSIR framework.

The analysis is presented for coastal archetypes from Spain, Ireland and Romania, sweeping a range of meteooceanographic and socio-economic pressures, resulting in a wide range of fluxes among them those related to sediment. The analysis emphasizes the variables that provide a higher level of robustness. That means mean sea level for physical factors and population density for human factors. For each of the studied cases high and low sustainability practices, based on stakeholders preferences, are considered and discussed. This allows proposing alternatives and carrying out an integrated assessment in the last section of the paper. This assessment permits building a sequence of interventions called adaptation pathway that enhances the natural resilience of the studied coastal systems and therefore increases their sustainability under present and future conditions.

(c) 2016 Elsevier B.V. All rights reserved.
\end{abstract}

\footnotetext{
* Corresponding author at: Jordi Girona, 1-3, Ed. D1, 08031 Barcelona, Spain.

E-mail addresses: agustin.arcilla@upc.edu (A. Sánchez-Arcilla), manuel.garcia-leon@upc.edu (M. García-León), vicente.gracia@upc.edu (V. Gracia), r.devoy@ucc.ie (R. Devoy), astanica@geoecomar.ro (A. Stanica), J.Gault@ucc.ie (J. Gault).
} 


\section{Introduction}

The dynamic state of the coastal fringe affects societies by providing a variety of resources. These natural services differ in magnitude and timing with end-users' demands, thus generating conflictive interactions. Coastal engineering provides a path to modulate these interactions, whose management needs a balance among different functionalities (natural, protection and support for socioeconomic activities). Coastal infrastructures such as harbours and coastal works are able to withstand meteooceanographic drivers and a growing sediment scarcity (Marchand et al., 2011). Design plus maintenance criteria are strongly related to the extreme values of hydrodynamic drivers, whose sharp gradients unleash a number of coastal hazards associated to erosion and flooding (Sanchez-Arcilla et al., 2014).

The maintenance of coastal functionality has been addressed with hard and soft solutions, both separately or in conjunction (Hamm et al., 2002). Traditionally, hard solutions comprise breakwaters, groins or revetments whereas beach nourishment, sediment by-pass and back-pass are considered as soft interventions (Hanson et al., 2002). Despite the local efficiency of hard structures at short term scales, they result in a permanent barrier which may exacerbate erosion or accretion patterns. Although hard interventions have alleviated some local problems they have also become the origin of new conflicts. Soft solutions provide a more flexible approach to undesired interactions but they require periodic maintenance and they are limited by progressive sediment starvation in many coastal tracts and river catchment basins (Ibáñez et al., 2014).

Changes in natural pressures can further distort beach functions, mainly at human-squeezed zones. Sea level rise (Church et al., 2013; Devoy, 2015b; Jevrejeva et al., 2014a), changes in wave patterns (Casas-Prat and Sierra, 2013; Wang et al., 2014) and storminess (Nissen et al., 2014) plus enhanced subsidence rates (Brown and Nicholls, 2015; Ibàñez et al., 1997, 2010) alter the natural coastal resilience and hamper a sustainable long-term coastal management. The high degree of uncertainty of these changes may hinder long-term planning and demands a flexible roadmap, able to adapt throughout its lifetime (Haasnoot et al., 2013).

These flexible roadmaps should combine impact mitigation and adaptation at two time-scales: long-term and episodic (storm related). The first one deals with relatively steady trends whereas the second one aims to transiently hinder storm impacts (Garcia-Leon et al.,
2015; Sanchez-Arcilla et al., 2015a). The use of transient defence measures (TDM) seeks to reduce storm hazards below a given threshold.

The overarching aim of this paper is to structure with objective criteria a set of interventions that could constitute an adaptive pathway to coastal sustainability. These interventions are based on a selection of case studies which show the range of physical/environmental factors (energy levels, biological habitats and geometric/geologic controls) and socio-economic/political settings present in our coastal systems.

This allows defining a number of coastal archetypes which illustrate the effect of climate factors on coastal systems, affecting drivers (D), pressures (P), coastal state $(S)$, impacts (I) and responses (R). This DPSIR framework (OECD, 1993; EEA, 1995; Kristensen, 2004; Pacheco et al., 2006) can be used to evaluate impacts and responses from a number of standpoints, including stakeholders' preferences.

The case studies span three European countries (Fig. 1): Spain, Ireland and Romania. The coast of Ireland represents the high energy range in terms of tides and waves while the NW Mediterranean coast and Danube delta (Black Sea) are examples of fetch-limited microtidal environments of moderate energy conditions mainly controlled by episodic extreme events. Although the legal and administrative settings are presently different they are subject to convergence under European Union common legislation and policy.

The range of hydrodynamic pressures and morphodynamic responses runs in parallel to a shared growth in human uses and infrastructures (see e.g. Woodroffe, 2002). This is the basis for an intercomparison that will serve to assess the relative success of various adaptation practices. Their efficiency under future climatic scenarios is controlled by the level of coastal squeezing (Cooper and Pilkey, 2012) and dominant physical features, being thus simultaneously dependent on climate change and human pressures. From here we shall recommend some criteria for more sustainable adaptation pathways in terms of cost, energy consumption and user preferences.

\section{Coastal archetypes}

The analysis of vulnerable coastal sectors requires a careful consideration of the dominant time/space scales to define domain boundaries for any subsequent assessment. For example, short term solutions may give rise to considerations about their compatibility with long term planning and policies. The vulnerability considered here will be that linked to short term or storm scales plus that due to decadal or
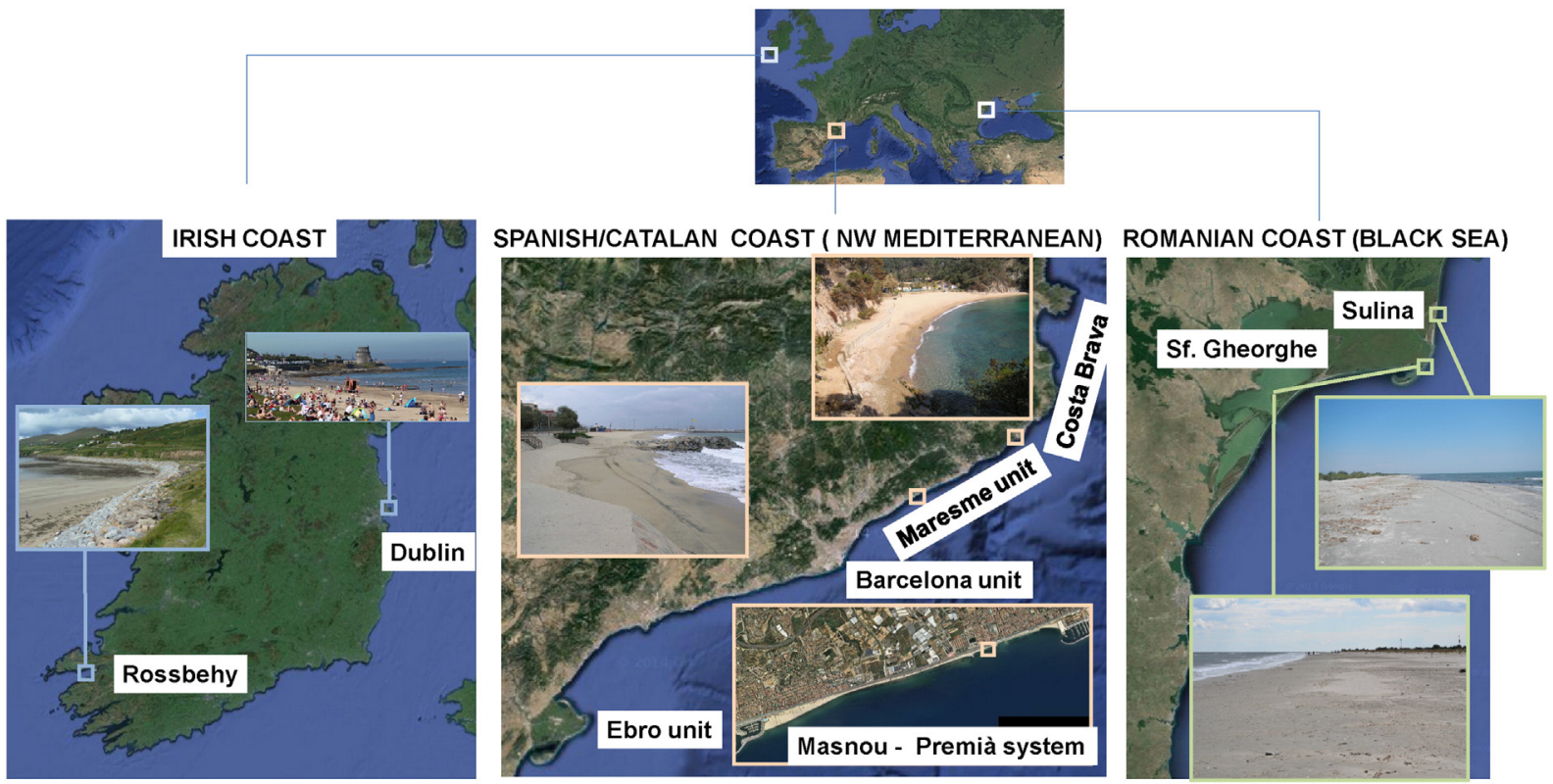

Fig. 1. Coastal archetypes from the Irish, Spanish and Romanian coasts. 
long term evolution of climatic drivers such as mean sea level. Within this context, the geological settings partly control the physical impact due to climatic variables. In the same manner the social and economic uses control up to a point the level of damages experienced by the coastal sector, since the underlying assumption is that natural systems, unless prevented by human action, are able to adapt to a varying climate until reaching a no return (tipping) point.

Any assessment needs a management unit which ensures that processes and functionalities are properly bounded. The littoral cell concept has been chosen as such unit because it represents a relatively closed system where emerged and submerged zones exchange sediment fluxes. Wind waves, tides and surges drive sedimentary transport, modulated by natural and anthropogenic barriers. Impounded transport coasts can be illustrated by pocket beaches or embayments where any conflict would be local, whereas free transport coasts would correspond to more general conflicts.

Sediment properties (grain size, cohesion, degree of organic material) constrain mobility, thereby bounding the impact level. In that sense, cliff coasts composed by hard rocks (e.g. volcanic) present the maximum resilience (Viles and Spencer, 1995), whilst fine sandy coasts show the maximum vulnerability and coarse clastic sedimentary settings (e.g. cobble or gravel dominated systems) characterise an intermediate situation (Orford et al., 1996; Duffy and Devoy, 1999; Devoy, 2008).

Social and economic uses control the consequences of such impacts, mainly for economic and social (cultural) values. Squeezed coasts feature higher vulnerability levels, due to the lack of space to retreat or adapt or the societal/political inability to make room for natural dynamics. Adaptable coasts with enough space to evolve represent sectors with a lower vulnerability and the capacity to develop a higher natural resilience. In what follows some examples of adaptation will be discussed, focusing on relatively extreme situations to be more illustrative.

Coastal areas with a higher energetic level, for a given geological setting, will experience a higher degree of mobility and therefore vulnerability, considering that human uses and infrastructures trend to be static. And yet coastal environments subject to a higher level of incoming energy are more naturally prepared to deal with climatic variability or change. As an illustration, for a given distribution of storm surge levels, a more vertical curve such as, for instance, the Irish coast will reflect a lower decrease of flooding return periods than a flatter surge curve such as for instance the Mediterranean or the Black Sea cases.

The selected coastal cases (typologies) present a variety of physical pressures, responses and suggest a range of possible interventions, which depending on scale and resource availability can be considered as sustainable or mal-adaptation practice, depending on the resulting vulnerabilities. Sustainability is here considered as the capacity to maintain the coastal system status at mid to long term (decadal scale), therefore with socio-economically acceptable impacts and costs. Low sustainability makes reference to a low probability of maintaining the coastal system while high sustainability makes reference to higher levels of the same probability. Because of that we have considered as low sustainability practices those that, although efficient in the short term, do not provide a plan for the mid to long term maintenance nor any assessment of the capacity to maintain the required human interventions. High sustainability has been considered as those practices that internalize costs and impacts at short to long time scales and therefore enhance the capacity for the coastal system for self-maintenance or facilitates the required human interventions. They can be illustrated by interventions associated to reducing sediment mobility by means of vegetation or increasing the available sediment volume by an integrated river catchment basin management.

The analysis performed in this paper does not intend to be comprehensive, but only to illustrate some of the pitfalls and limits of commonly employed coastal interventions and how to make them more compatible with future climate change.
The study focuses on different coastal archetypes across Europe, defined by the following criteria (Table 1): (i) sediment transport and budget features, (ii) capacity of drivers to mobilize (erode and deposit) sediment and (iii) level and type of socio-economic uses. The NW Mediterranean sea case presents wave-driven impounded beaches in a squeezed littoral, representative of other zones such as Italy, Southern France or Greece. The Irish case has longer littoral cells and its hydrodynamic drivers are mixed (waves plus tides) and similar to other North Sea coastal tracts in Europe (UK, Netherlands). The Romanian case presents drivers comparable to those of the NW Mediterranean case, but with a lower level of coastal occupation.

Some of the proposed interventions can be considered as milestones towards an adaptive plan for coastal sustainability under climate change. In countries where there is not such an adaptive strategy, these individual actions can highlight the need for a more ambitious plan to manage properly the entire coast and not particular transects.

\section{Climate and human change factors}

Coasts (globally) are recording increasing changes in their functioning and vulnerability under a range of environmental drivers (Carter and Woodroffe, 1994; Devoy, 2008, 2015b; Cooper and Cummins, 2009; Masselink et al., 2011). These include changes in sea-level rise (SLR) and associated marine flooding (Fang et al., 2014), changes in wave climate regimes (Wang et al., 2014), in river liquid discharges (Alfieri et al., 2015) and modified sediments fluxes (Hinkel et al., 2013).

Low-lying coasts are one of the most vulnerable zones due to these climate issues with deltas representing historically highly populated littoral systems (Brown et al., 2013). In this latter case subsidence poses an additional threat, caused by both natural (tectonics, compaction, degree of organic material, etc.) and anthropogenic (land-uses, groundwater or hydrocarbon extraction, erosion control structures, etc.) factors. In some cases, the relative-sea-level-rise (RSLR) doubles or even triples the SLR. For instance, in the Ebro Delta wetlands (Section 4), the RSLR ranges from 5 to $8 \mathrm{~mm} / \mathrm{yr}$ (Ibáñez et al., 2010). Together, all these factors result in accelerated levels of erosion and may force retreat in significant sectors of the world coasts (Hinkel et al., 2013; Syvitski et al., 2009; Woodroffe, 2002).

Direct human impacts (urbanization, structures, river regulation) condition coastal vulnerability and are the primary factors for the evolution of developed (e.g. European) coasts (Cooper and Pilkey, 2012). Climatic change, linked to global warming of the Atmosphere-Ocean (A-O) system, results in thermal expansion of ocean water (steric effect) and the addition of land-based ice meltwater. This causes most of the observed SLR (Church et al., 2013; Devoy, 1987, 2015b).

Recent past observations show global mean sea-level changes (GMSL) since the 1880 s of circa $0.2 \mathrm{~m}(0.19 \mathrm{~m}, 1901-2013)$ at averaged rates of $1.7-1.8 \mathrm{~mm} / \mathrm{year}$, though with strong temporal (decadal scale) and regional variations (Devoy, 2015b; EEA, 2014; Jevrejeva et al., 2014b; Menéndez and Woodworth, 2010). During this interval mean global sea-surface temperatures (SST) have also risen by circa $0.8^{\circ} \mathrm{C}$, altering storminess in many ocean regions (IPCC, 2013; IPCC, 2014; EEA, 2014).

Future climate projections for European coasts, based on model ensembles, show SLR rates similar to global values (Lowe et al., 2010; Church et al., 2013). For low greenhouse gas (GHG) emission scenarios (SRES B2-A1B; RCP 2.6) mean SLR is likely to be in the range of 0.26$0.54 \mathrm{~m}$ above 1990 levels by 2080-2100. For higher emissions (SRES A1F; RCP 8.5) mean SLR will be in the range $0.45-0.81 \mathrm{~m}$ and continuing to rise between $1-3 \mathrm{~m}$ by 2300 (EEA, 2014), depending on levels of continued GHG emissions.

Current satellite altimetric observations of SLR rates for European waters, also supported by tide gauge data, commonly show values above 3.2-3.4 mm/yr (EEA, 2014), except for regions of significant geotectonic subsidence (e.g., deltas and seismically active plate margins) or 
Table 1

Physical and socio-economic features characterising the selected coastal cases (archetypes for similar littoral systems)

\begin{tabular}{|c|c|c|c|}
\hline & $\begin{array}{l}\text { Western Europe } \\
\text { (Catalonia - Spain) }\end{array}$ & $\begin{array}{l}\text { Northern Europe } \\
\text { (Ireland) }\end{array}$ & $\begin{array}{l}\text { Eastern Europe } \\
\text { (Romania) }\end{array}$ \\
\hline Sediment connectivity & Impounded & Partial & Open \\
\hline Meteo-Oceanographic pressures & $\begin{array}{l}\text { - Gradient storms } \\
\text { - Transient surges }\end{array}$ & $\begin{array}{l}\text { - Composite sea-swell } \\
\text { - Tidal ranges and surges }\end{array}$ & $\begin{array}{l}\text { - Gradients storms } \\
\text { - Transient surges }\end{array}$ \\
\hline Socio-economic pressures & $\begin{array}{l}\text { - High population density. } \\
\text { - Developed economy }\end{array}$ & $\begin{array}{l}\text { - Median population density } \\
\text { - Developed country }\end{array}$ & $\begin{array}{l}\text { - Low population density } \\
\text { - Developing economy }\end{array}$ \\
\hline
\end{tabular}

affected by continuing postglacial isostatic uplift (Fig. 3). These rates are likely to accelerate beyond $4-5 \mathrm{~mm} / \mathrm{year}$ by the mid 21 st century.

Model projections indicate anomalies in wind fields whose average intensity tend to a poleward shift in Northern Europe (Lionello et al., 2008; Nissen et al., 2014). However, at the Mediterranean basin there is a less definite trend (Planton et al., 2012). These wind anomalies may imply changes in wind wave patterns, affecting directionality and mean significant wave height (CasasPrat and Sierra, 2013). The same authors, through outputs from AR4 scenarios and for the 2071-2100 period at the NW Mediterranean Sea, presented a significant wave height variation around $\pm 10 \%$ whereas the same variable for a 50 year return period varied within a $\pm 20 \%$ interval.

Similar evolution trends apply to storm surges although in all cases due attention should be paid to the different behavior of mean trend and variance characterizing storms (Lowe et al., 2010). For instance, (Conte and Lionello, 2013) presented variations up to $\pm 5 \%$ for both positive and negative surges in the Mediterranean Sea.

The downscaling for semi enclosed basins (e.g. the Mediterranean Sea) is complex, becoming more difficult for smaller sub-basins (e.g. the Black Sea and Danube Delta, see Stanica and Panin, 2009; Stanica et al., 2013). Coastal processes and SLR at such local scales are driven by regional steric (temperature) effects, precipitation-evaporation balance, river inflows and other oscillations at various frequencies (e.g. water exchanges between the Mediterranean and North Atlantic) (Tsimplis et al., 2004; Dan et al., 2009; Valchev et al., 2012).

Sea levels in the Black Sea have risen by $2.5 \mathrm{~mm} / \mathrm{yr}$ since the $1990 \mathrm{~s}$ and by $1.5 \mathrm{~mm} / \mathrm{yr}$ in the Western Mediterranean, with current satellite records showing an acceleration of SLR commensurate with the wider European and global patterns of SLR curves (EEA, 2014). Although downscaled A-O GCM experiments are not well developed for the Mediterranean/Black Sea region, model projections show the continuation of this SLR trend up to 2100, coupled with regional rises in temperature (Church et al., 2013).
In Fig. 2, SLR projections for the RCP 2.6, 4.5 and 8.5 scenarios are presented at the nearest node of the selected case studies. The Western Irish Coast (Fig. 2b) is the zone where higher SLR and uncertainties appear. The $90 \%$ confidence interval presents values near $1.1 \mathrm{~m}$ for RCP 8.5 , whereas the Mediterranean zone show less uncertainty and lower mean values. The NW Mediterranean has lower values than the Eastern Mediterranean, following the trend that the altimeter observations (EEA, 2014) highlighted.

Note also that the mean trends of RCPs tend to diverge in the second part of the twenty-first century. This behavior (discussed also in Section 7) can, thus, convey a misleading message at the beginning of this century and can even justify postponing response decisions, since the larger part of the uncertainty (and impacts) will start to happen by 2040-2050.

The likely future increase in population for our studied coasts (Neumann et al., 2015), associated to industrialization, urban growth and expanding tourism, will bring the numbers of people living in the littoral closer to the levels elsewhere in Europe. This means more than $25 \%$ of Europe's current population living at the coast (IPCC, 2014). Continuation of the established upward trend in this population growth will increase the vulnerability of coasts to the impacts of future SLR and storminess under climate warming.

In Fig. 3 the population growth projections are presented (from 1960 to 2010, the historical data is from World Bank country database) based on the (IIASA, 2012) database. Each projection belongs to a SSP (O'Neill et al., 2014) family, covering the following pathways: SSP1 (sustainability), SSP2 (middle of the road), SSP3 (regional rivalry), SSP4 (inequality) and SSP5 (rapid growth).

Lower population is expected in the SSP3 narrative, because its represents a future in which the countries are almost self-sufficient with minor trades and exports. However, SSP5 represents a rapid growth with expenditure for mitigation strategies. Note that the SSP5 in the Spanish and Irish case follow the same population gradient than the last decade (2000 onwards) in which both have experienced a rapid (a) NW Mediterranean Coast

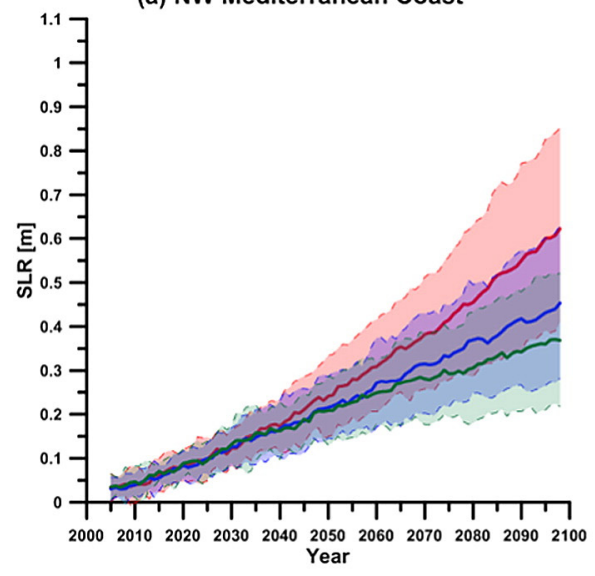

(b) North-Atlantic Ireland coast

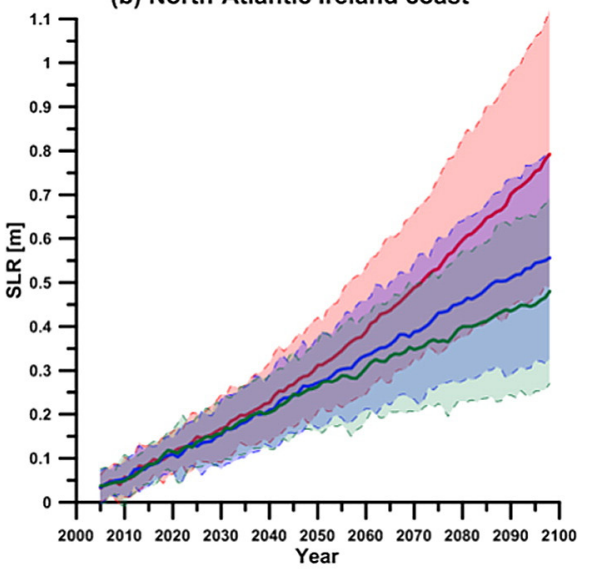

(c) Eastern Mediterranean Coast

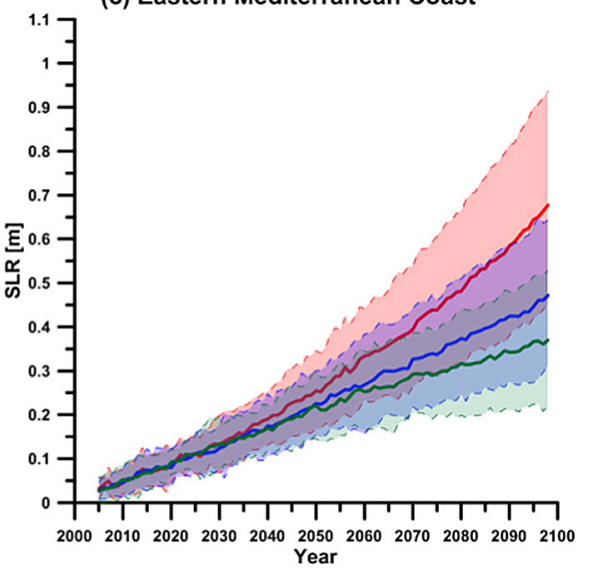

RCP 8.5

RCP 4.5

RGP 2.6

Fig. 2. Projected regional rise in sea level up to 2100 at the nearest node of the selected case studies. 


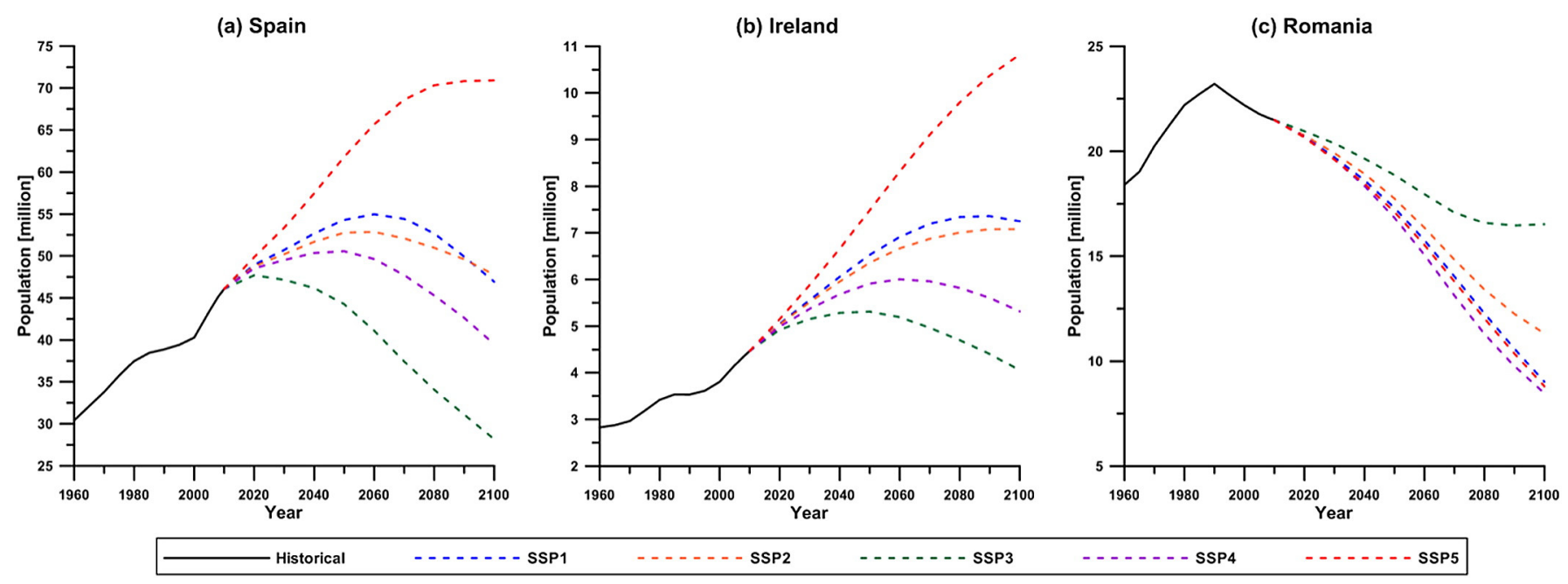

Fig. 3. Projected population from 2010 to 2100 at the three analyzed countries. (Source: IIASA, 2012)

growth. Nevertheless, the common trend in Spain is towards stabilization (except in SSP5 and SSP3); Ireland presents mild growth and Romania shows depopulation gradients (by migration) similar to the previous two decades.

\section{The Spanish case}

\subsection{Coastal description}

The Spanish coastline has an approximate length of $7900 \mathrm{~km}, 50 \%$ of which consists of hard and soft cliffs (especially present at the Atlantic border) and about $25 \%$ is comprised of sandy beaches. This situation of geo-diversity is well represented by the Catalan coast, $800 \mathrm{~km}$ long and located in the Spanish Mediterranean.

The Catalan coast presents almost all type of littoral environments. The northern sector is composed by the presence of cliffs (about $280 \mathrm{~km}$ of the total length) and prominent headlands delimiting pocket beaches that span a vast range of dimensions and are typically of coarse sediment. The southern part is typically represented by low lying beaches of fine sediments. The central part is under the influence of the metropolitan area of Barcelona and concentrates most of the marinas and urban settlements which have created a segmented coastal landscape due to an important coastal protection activity. The main morphological features are the Ebro delta unit at the south (a $50 \mathrm{~km}$ sandy fringe), the straight segmented and relatively coarse sand beaches at the centre (represented by the Barcelona-Maresme system) and the Tordera delta and Costa Brava pocket beaches and cliffs at the North tract (see Fig. 1).

This coast is located in a micro-tidal and fetch limited environment. The astronomical tidal range is less than $0.4 \mathrm{~m}$ although during storms the associated surge can reach values up to $1 \mathrm{~m}$. The mean offshore significant wave height for the area is $0.7 \mathrm{~m}$ with an associated wave period of $7 \mathrm{~s}$. The directional distribution of waves at the Northern and Southern parts of the coast show a predominance of NW and N components whereas at the central part the East and South directions are dominant. There are two main meteorological patterns for wave storminess (Bolanos et al., 2009): an intense high-pressure centre on the British islands which induces strong NE and $\mathrm{E}$ winds and a Mediterranean cyclo-genesis in front of the Catalan coast generating $\mathrm{E}$ winds. The maximum recorded Hs is about $6 \mathrm{~m}$ (with Hmax up to $10 \mathrm{~m}$ ) and peak periods of about $14 \mathrm{~s}$. Fig. 4 shows the wave directional diagrams at different locations along the coast obtained from the existing wave buoys for the period 1984 to 2007. As it can be seen north-eastern and Eastern components feature the highest waves whereas the southern component, although present, has typically lower values. There is no direct correlation between wave storms and surges, meaning that storms can be found in wave records with and without an associated mean water level surge.

Natural and artificial barriers modulate sediment dynamics and divide the coast into 22 littoral cells (CIIRC (2010)). The average beach has a width of about $37 \mathrm{~m}$, with a mean sand size from 0.2 to $1.8 \mathrm{~mm}$ (median value of about $0.7 \mathrm{~mm}$ ) and a foreshore slope steeper than $1 /$ 10. The spatial distribution of sediment along the coast reflects the differences in river basins, which have historically provided solid discharges to the coast, later reworked by wave action. Beaches located close to the mouth of the main rivers present sediment finer than for beaches fed by ephemeral stream flows (usually very short). This general pattern has been modified in the last decades by the supply of allocthonus sediments (of marine and terrestrial origin) in a considerable number of beach nourishment operations that have created an artificial morphodynamic signature in most of the beaches. As an example of this alteration, only in the central part of the Catalan coast more than 10 millions of sand have been supplied in different beach nourishment operations during the last 20 years (Gracia et al., 2013b).

Urban sandy beaches are typically bounded in their backside by a seafront promenade and infrastructures like streets, roads, railways and houses. In the last years, the maintenance and development of promenades has been one of the major investments undertaken by the Spanish government, with more than $50 \mathrm{M} €$ only in Catalonia during the last two decades (CEDEX, 2013; Hamm et al., 2002).

The shoreline changes for the period 1995-2004 show a general retreat, with more than 70\% of Catalan beaches eroding (CIIRC, 2010), with average rates of about $-2.1 \mathrm{~m} / \mathrm{yr}$ and of about $-3.3 \mathrm{~m} / \mathrm{yr}$ when the Ebro delta is considered. Only $24 \%$ of the beaches have experienced accretion with an average rate of about $+1.5 \mathrm{~m} / \mathrm{yr}$. and mainly correspond to areas located at the end of coastal cells which bank up the sediment from the upstream part of the cell or, in the particular case of the Ebro delta, from its ending spits.

\subsection{Low sustainability practices}

It is accepted that the urban development at the Catalan coastal started in the 70s under low regulatory conditions (Malvarez et al., 2000). The lack of a general management strategy followed by the construction of coastal promenades, second houses (fed by tourism needs) and existing urban growth pressure jointly with the regulation of river basins have led to the present sediment starvation needing coastal protection. 


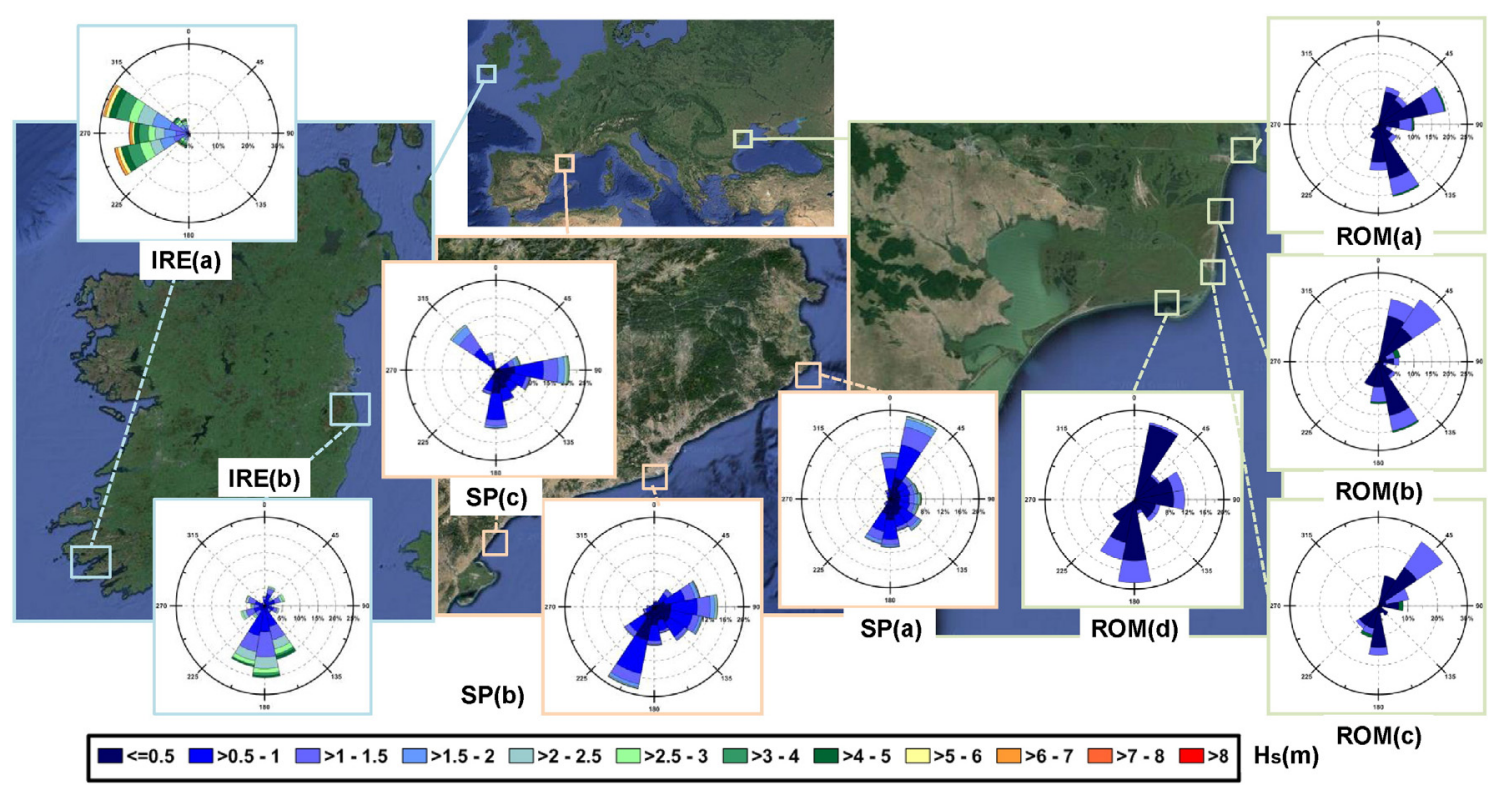

Fig. 4. Wave climate at the coasts of Ireland, Spain (NW Mediterranean) and Romania.

The urban development has resulted in high population density along the coastal fringe (6.000-7.000 persons/ $\mathrm{km}$ of coast when permanent residents plus tourists are considered). This squeezing requires a minimum beach width to support coastal functions and also to defend the hinterland (infrastructures and territory). During the second half of the 1980s and early 1990s, beach nourishment was the common solution to fight against erosion, with more than $10 \mathrm{Mm}^{3}$ in about 10 years of which only small fraction remains in place. This situation has been pointed out by some recent research (Eurosion, 2004; Gracia et al., 2013b, Marchand et al., 2011).

The lack of a general coastal master plan to fight against erosion, the difficulty to obtain suitable volumes of sediment with enough quality plus the present economic situation has led to the present management strategy, where actions are taken after the impact. This reactive management also includes the "no active intervention" policy, resulting often in a degenerative beach state.

The Central part of the Catalan coast (excluding the Ebro system), that is the Barcelona-Maresme coastal stretch, is an example of such situation. The area is the longer tract with eroding beaches and also where most of the locally accretive beaches are found. This behaviour is basically due to the net littoral drift, from north to south, and the existence of numerous marinas interrupting the alongshore dynamics. This restriction creates a local shoreline retreat at the beaches in the north of the cells and a lower accretion at the southern part of the cells, linked to the downstream barrier.

The area is directly exposed to the most energetic wave events (Eastern component) and has a backside limit due to an almost fully occupied territory (settlements and infrastructures). This situation blocks the natural onshore dynamics typically observed during high energy episodes. Coastal segmentation has created a sediment redistribution pattern which is incompatible with the socio-economic demand of a minimum homogeneous emerged beach width along the sector. The alongshore sediment blockage generated by the construction of structures and the near total decrease of river sediment supply (large enough in size to be stable for the emerged beach) has resulted in a sediment budget imbalance in most littoral cells.

The existence of these artificial obstacles has also created a divergence in alongshore sediment transport, generating local erosional hot spots south of the barriers which lead to important local losses of emerged beach (see Fig. 5). The periodic beach nourishment of those areas or/and the construction of small groins constraining sediment mobility have been common strategies carried out for maintaining beach width. However, the high erosion rates and the limited availability of suitable sediment cast some doubts on the sustainability of such an approach, normally interrupted whenever the economic or environmental situations make this solution unacceptable. This has led to the construction of alongshore riprap revetments to defend certain sectors.

The deployment of groins to increase the residence time of the sediment within the cell has also proved to be fruitless (CEDEX, 2013; Jimenez et al., 2011). Two main processes can explain such behaviour: a) the creation of offshore currents that transport sediment out of the cell towards deeper regions and b) the re-orientation of the shoreline parallel to the most energetic wave trains. In the first case, although the sediment does not leave the domain, it is deposited in an area where only high wave conditions can return it to the coast, leading to a growing deficit of emerged sand volume. The shoreline re-orientation is highly sensitive to the incident wave direction. In these beaches waves act very obliquely to the shoreline due to the small periods and manmade obstacles can only retain a limited sand volume, with sediment rapidly reaching the head of the groins and by-passing it towards the down drift sector (Jimenez et al., 2011; Sanchez-Arcilla et al., 2014, 2015a).

The complexity of these morphodynamic processes has led to two main management strategies: a patchy (discontinuous) maintenance and armouring of the coast and the small partitioning into coastal cells that will next be subject to an almost complete closure with submerged breakwaters (e.g. Barcelona urban beaches). However, neither option has allowed the maintenance of a homogeneous beach width. Two main processes can explain such non desired dynamics: a) the segmentation creates a subset of diffraction points that form logarithmic shaped bays with less width at the centre and wider areas at the borders and b) the natural cyclic onshore-offshore coastal dynamics which favours an offshore transport of finer sediments, reducing the width of the emerged beach. This has resulted in low sustainability for a narrow coastal fringe that presents a high level of vulnerability under present and future climates.

\subsection{High sustainability practices}

Due to the scarcity of sediment for many sectors in the Catalan coast the actions undertaken in the last 20 years (also extensive for the rest of the Spanish territory) have been unsuccessful to maintain a sandy belt as required by tourism and hinterland protection. New coastal strategies incorporating the whole river catchment basin and targeting 


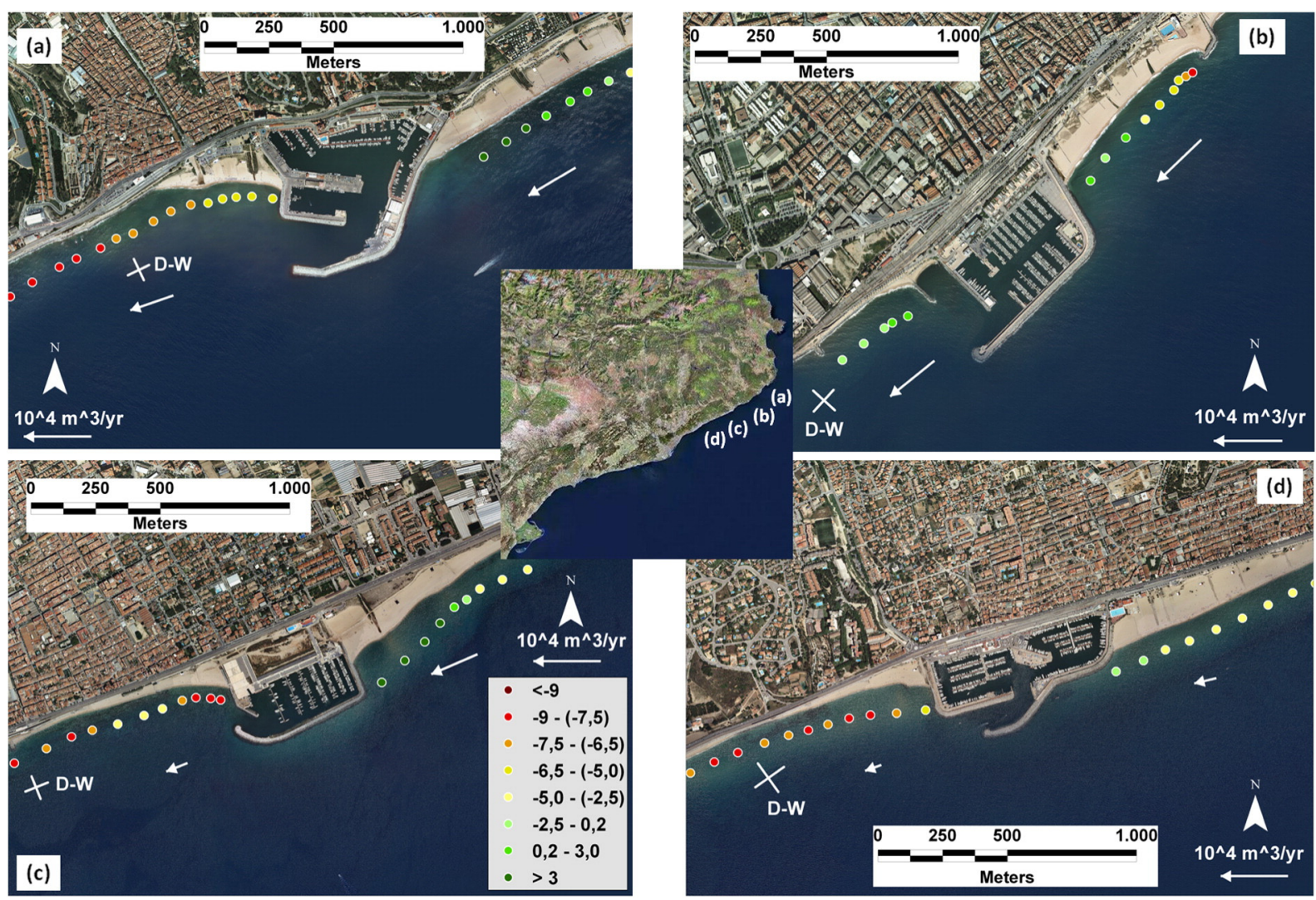

Fig. 5. Erosional hotspots southwards Catalan harbours.

medium to long term scales, moving from protection to a more proactive policy will increase the overall coastal sustainability. The Spanish Ministry of Environment is preparing such a plan under the principles that coastal management should consider sediment availability and climate change plus a commitment to "integration" regarding scales and uses. However, there has not yet been a general implementation of the plan and in many cases coastal management continues along the old track. Because of that, municipalities are starting to play a more active role demanding not only economic resources but also making proposals for maintaining a minimum beach width to ensure beach functions (Section 7).

An illustration from the coast south of Barcelona will be presented in what follows, showing the feasibility of sustainable shoreline retreat (Fig. 6). The observed erosion is the result of combined human and natural factors, making it difficult to establish a main culprit. The expansion of Barcelona harbour with the construction of a long jetty (down to $8 \mathrm{~m}$ water depth) in the Llobregat River (Fig. 6) has shortened the supply of sediment from the North. A small craft harbour (Port Ginesta) closes the

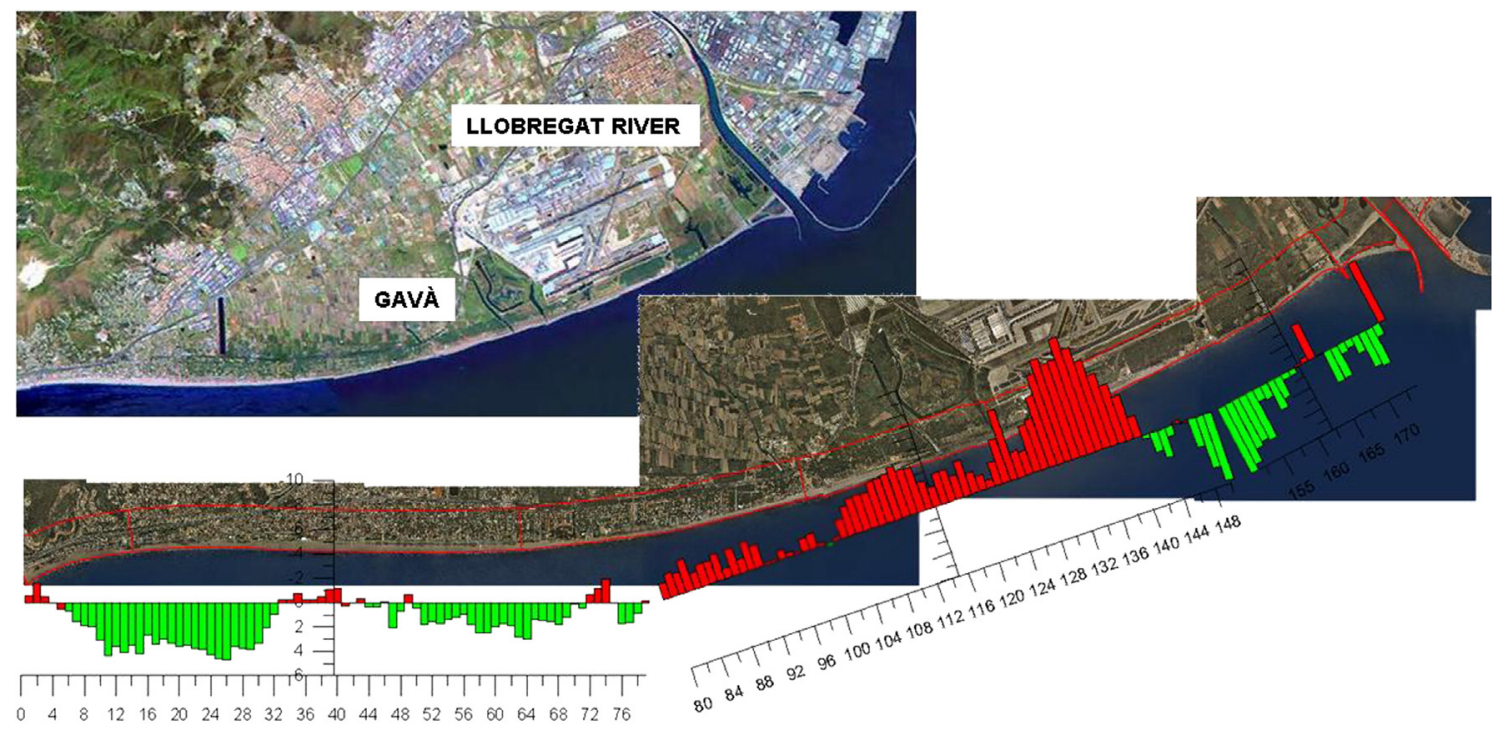

Fig. 6. Shoreline changes in south Barcelona harbour during the period 2004-2010. 
cell at the South. The sequence of southern and northern storm waves is no longer able to produce alongshore sediment fluxes in the two shore parallel directions (senses). The barrier effect enhances cross shore transport (losses) and prevents river discharges to supply sediment to the active coastal profile.

The coastal management plan for the area consists of periodic nourishments that back-pass sand from the southern end of the littoral cell to the northern border. However, after almost one million cubic meters of sand nourished in the last 6 years, the desired effects have not been achieved and at present some of the beaches present an alarming reduction of emerged width. This is due to the difficulty of finding suitable sediment sizes since the expected alongshore winnowing results in a grain size classification providing only the finer fractions at the end of the unit (the more frequent source areas).

Taking all those aspects into consideration, the Gava municipality has proposed a maintenance plan where the main target is to safeguard a minimum emerged width. Based on this an initial nourishment has been designed taking the sediment from the emerged and shallow neighbouring beaches instead of looking for sources outside the littoral cell. Sediment placement has also been designed to have a smooth coastline shape in order to reduce longshore sediment transport gradients (LIM/UPC, 2014). Besides, at the back beach an ephemeral small dune of $1.5 \mathrm{~m}$ has been proposed to protect infrastructures from storm events of 15 years return period. The dune acts also as a sediment buffer which will naturally feed the area, thus enhancing the presence of an emerged beach. Fig. 7 shows the dune/beach profile response at different locations selected for testing the design using a modified XBEACH model (Roelvink et al., 2009). The parameters of the model have been calibrated with similar dissipative beaches in the neighbourhood (Gracia et al., 2013a).

The main morphodynamic changes are found between the -0.5 and $2 \mathrm{~m}$ isobaths. Several dune layouts were tested showing similar morphodynamic simulations: erosion at the emerged part and sand accumulation in the submerged part. This general behaviour can be explained by the relatively steady offshore wave climate for return periods from 2 to 15 years (meteo and fetch controlled).

The simulated behaviour shows an increase in sand transport under storms. This leads to erosion at the emerged part of the profile and accumulation in the submerged part. For extreme wave conditions and under high mean sea levels, the beach response is a scarp that enhances erosion. After a set of storms the beach natural recovery becomes harder and requires higher energy swells (uncommon in the area) or artificial means.

The averaged loss of sand with the transient dune during storms (spanning from 5 to 15 years return periods) is around $15,000 \mathrm{~m}^{3}$. Water depths from 0 to $2 \mathrm{~m}$ present an accretive behaviour (around
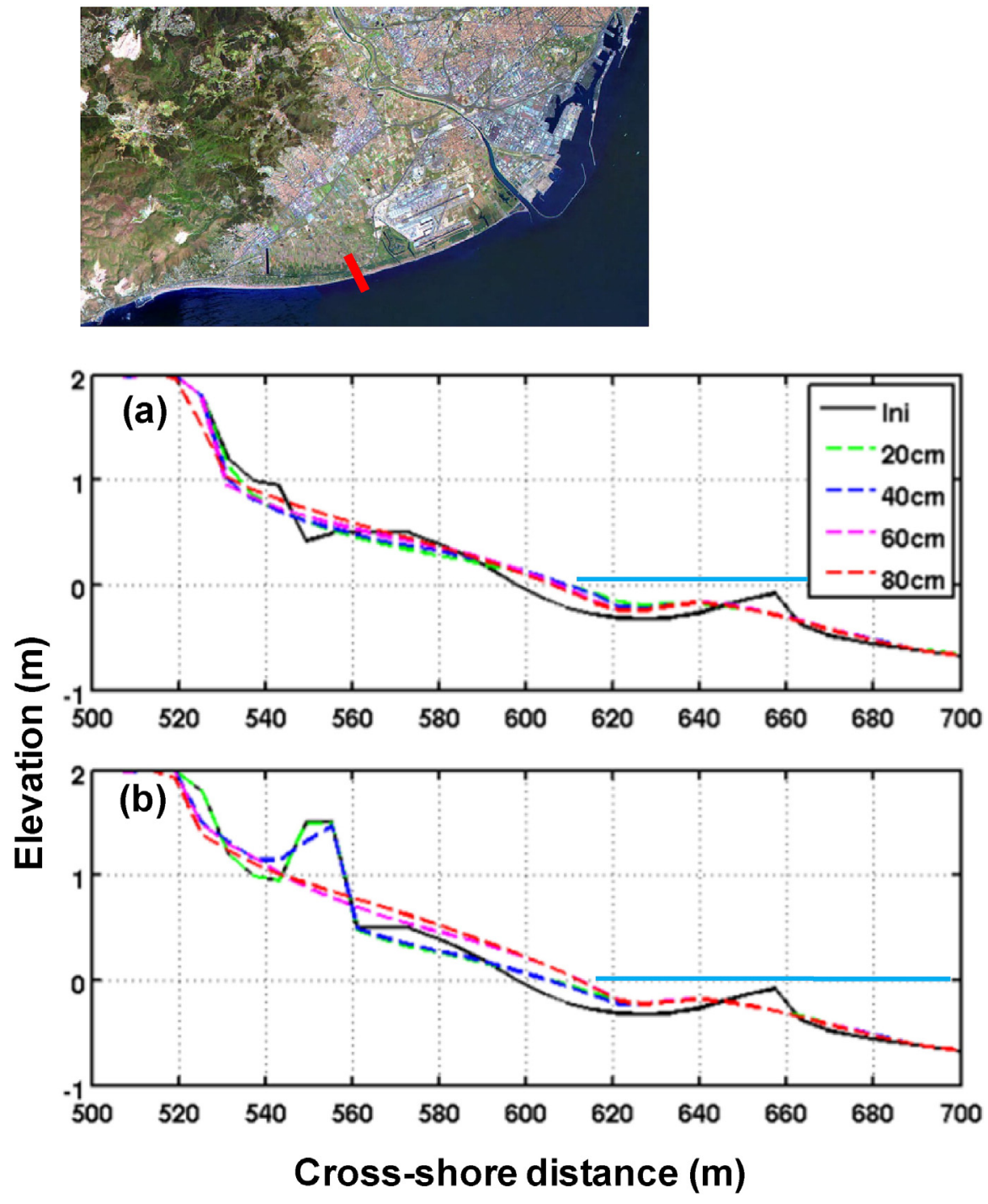

Fig. 7. Transient dune alternatives and storm response at Gavà beach (NW Mediterranean). 
$7000 \mathrm{~m}^{3}$ ). Longshore currents play an important role (around $0.4 \mathrm{~m} / \mathrm{s}$ in average), with littoral drift mobilising significant sand volumes southwards.

The emerged zone flattens when the dune collapses. Note that at Fig. 7, the dune starts to fail not under a collision regime (erosion at the offshore side) but because of overtopping volumes from the storm peak. The dune can withstand increases of $40 \mathrm{~cm}$ in mean sea levels that would correspond to a present storm surge or a future climatic rise. Beyond that point, the dune entirely collapses and sea level has a more prominent effect in the morphodynamic signature. This is because as waves increase, more sediment can be advected onshorewards, reaching a maximum for elevations between 1.5 and $2 \mathrm{~m}$.

Permanent monitoring of beach evolution and the main driving factors (waves and mean water level) has been proposed to support objective decisions and an ephemeral set of transient defence measures. The concept behind these interventions is linked to the difficulty of guaranteeing permanent protection and accepting a permanent maintenance of the beach. The idea of ephemeral defences has been taken into consideration in other European regions (Harley and Ciavola, 2013) and assessed numerically for some nearby beaches (GarciaLeon et al., 2015). Such transient measures must go together with a forecasting (early warning) system that supports dynamic interventions or maintenance of the beach.

Another case of high sustainability practices can be designed for the Ebro Delta, $200 \mathrm{~km}$ south of Barcelona. Flooding and erosion are considered as the most important risks by stakeholders (Rovira et al., 2014). This is due to the scarcity of sediment arriving from the regulated river catchment basin. Providing additional sediment volumes for offsetting subsidence and horizontal erosion would be an illustration of working with natural processes to increase resilience. This could be achieved by regulated floods from riverine and marine origins (Ibáñez et al., 2014; Sanchez-Arcilla et al., 2015b).

\section{The Irish case}

\subsection{Coastal description}

Ireland's coasts are dominated by high wave energy conditions, developed under North Atlantic storm patterns, and with 2-4 m range meso- to macro-tidal regimes. Mean significant wave heights (see Fig. 4) larger than $3.5 \mathrm{~m}$ in winter occur on fully exposed western coasts, reducing eastwards into the more protected and shorter fetch conditions of the Celtic and Irish Seas to values smaller than $2 \mathrm{~m}$ (Vijaykumar et al., 2006; Jenkins et al., 2009; O'Shea and Murphy, 2013). The inherited glacial 'soft' sediments comprising many of these coasts commonly show mean erosion rates of $0.5-1.0 \mathrm{~m} / \mathrm{yr}$ under current rates of sea-level rise (SLR). Sediments from these eroding tracts, coupled with past high onshore sediment supply during the early to mid-Holocene, have resulted in the formation of many beach-dune-barrier structures, of varying dimensions (e.g., $1-5 \mathrm{~km}$ in length, $0.5-1.0 \mathrm{~km}$ width and 5-more than $20 \mathrm{~m}$ height above beach level). In turn, these have allowed the development of extensive low energy back-barrier lagoon and wetland systems, in many locations linked to estuary environments.

The appropriate management of these beach-dune-barriers is problematic, as they are natural attractors for people, uses in agriculture (e.g. animal grazing and cultivation), sand and mineral resource extraction, coastal housing, infrastructural developments and in local recreation to wider tourism activities (see e.g. Delaney et al., 2012). Under future impacts of accelerated SLR, storminess and increased coastal erosion rates, these systems are likely to undergo significant changes in structure and position, as part of a general coastal squeeze (Cooper and Pilkey, 2012). Contrasting examples of approaches in dealing with the management of these systems exist in Ireland, emphasising the difficulties in finding management techniques acceptable at local community levels, but also consistent with good coastal governance and best practice' management options (Cooper and Cummins, 2009; Devoy, 2008; Gault et al., 2007; Gray et al., 2014).

\subsection{Low sustainability practices}

On the high energy Atlantic margin of Europe occur the prominent beach-dune-barrier systems of Inch and Rossbehy, formed at the head of Dingle Bay, southwest Ireland (Figs. 1 and 8). These two 'spit-like' structures have formed within a long (c.40 km) and narrow (c.10 km) sedimentary compartmentalised embayment and are controlled by a mixed wave and tide dominated regime (Devoy, 2009; Kandrot et al., 2014). The beach has sediment with a D50 of $0.235 \mathrm{~mm}$, with a relative tidal range (RTR) of $2.9 \mathrm{~m}$ and a dimensionless fall velocity $(\Omega)$ value of 6 . These spits developed under Holocene sea-level rise (SLR) on NorthSouth aligned glacial end-moraines were formed at the end of the last glacial stage (MIS 2-4) and are orientated normal to the present onshore wave action (Devoy, 2015a).

Minor drift-aligned shoreline spits are found at the distal ends of these barriers. Today, the barriers are separated by an ebb-tidal delta, but probably developed initially as a single structure across the bay in the early- to mid-Holocene through sediment rollover mechanisms under SLR (Devoy et al., 1996; Devoy, 2015a). This early barrier was breached circa 3000 years BP, leading to the formation of the present spit-like morphologies (Delaney et al., 2012).

Extensive back-barrier freshwater wetland and fluvial environments formed behind this feature, before changing to intertidal wetlands post breaching. Whilst the Inch Spit appears to be relatively stable today, Rossbehy was breached by a storm surge in 2008. The loss of dune volume reached a maximum of $530,000 \mathrm{~m}^{3} / \mathrm{yr}$ in 2008 and culminated in the 13-14 December 2008 breach which left a small northern island at around $500 \mathrm{~m}$ from the southern dune systems at high water (Williams et al., 2015). Henceforth, the erosion rates continue at rates of $30-50 \mathrm{~m} / \mathrm{yr}$ along its core-length and at circa $25 \mathrm{~m} / \mathrm{yr}$ on the seaward shore face, with the breach doubling in size to $1400 \mathrm{~m}$ width from 2012-2014.

Breaching events will likely become more frequent in response to rising sea levels due wave action at higher elevations across beach and dune profiles (Williams et al., 2015). Under future SLR associated to climate warming (about $0.8 \mathrm{~m}$ SLR by 2100 for the RCP 8.5, see Section 3) this structure may disintegrate, with significant impacts on Inch and the morpho-hydrodynamics of neighbouring coastal systems, though the barrier may reform in part or possibly move further east on land (Church et al., 2013; O'Shea and Murphy, 2013; Devoy, 2015a).

These barriers and adjacent wetlands have attracted persistent attention as a valuable location for coastal geomorphological and wider science research (e.g., Duffy and Devoy, 1999; Orford et al., 1997). The dunes on Inch particularly have been recognised as ecologically and floristically significant and classified as a Special Area for Conservation and Scientific Interest (SAC/SSIs), (NPWS, 2011). For the wider public, the visual attractiveness of the area is considered as high, which has been important in causing not only a persistent growth since the 1980s in tourist and other recreational users to Inch and Rossbehy, but also as a draw for coastal housing (both first and second homes) and small business developments.

The growth in buildings in the immediate back-barriers areas (more than 100 houses situated below $10 \mathrm{~m}$ mean sea level) has added significantly to the area's infrastructures (e.g. roads, harbours, jetties). Earlier buildings were linked more to the needs of the local primary industries such as farming, fishing and aquaculture.

This people-attraction factor is of particular importance now, due to the vulnerability of these environments to coastal flooding, erosion and cliffing-slope instability and collapse (Devoy, 1992, 2008; KCC, 2001; O'Connor et al., 2010). The consequences of this vulnerability for investment have been costly, in terms of demands for increased coastal protection works and earlier in the 19th and 20th Centuries in extensive land reclamation schemes (Duffy and Devoy, 1999). 


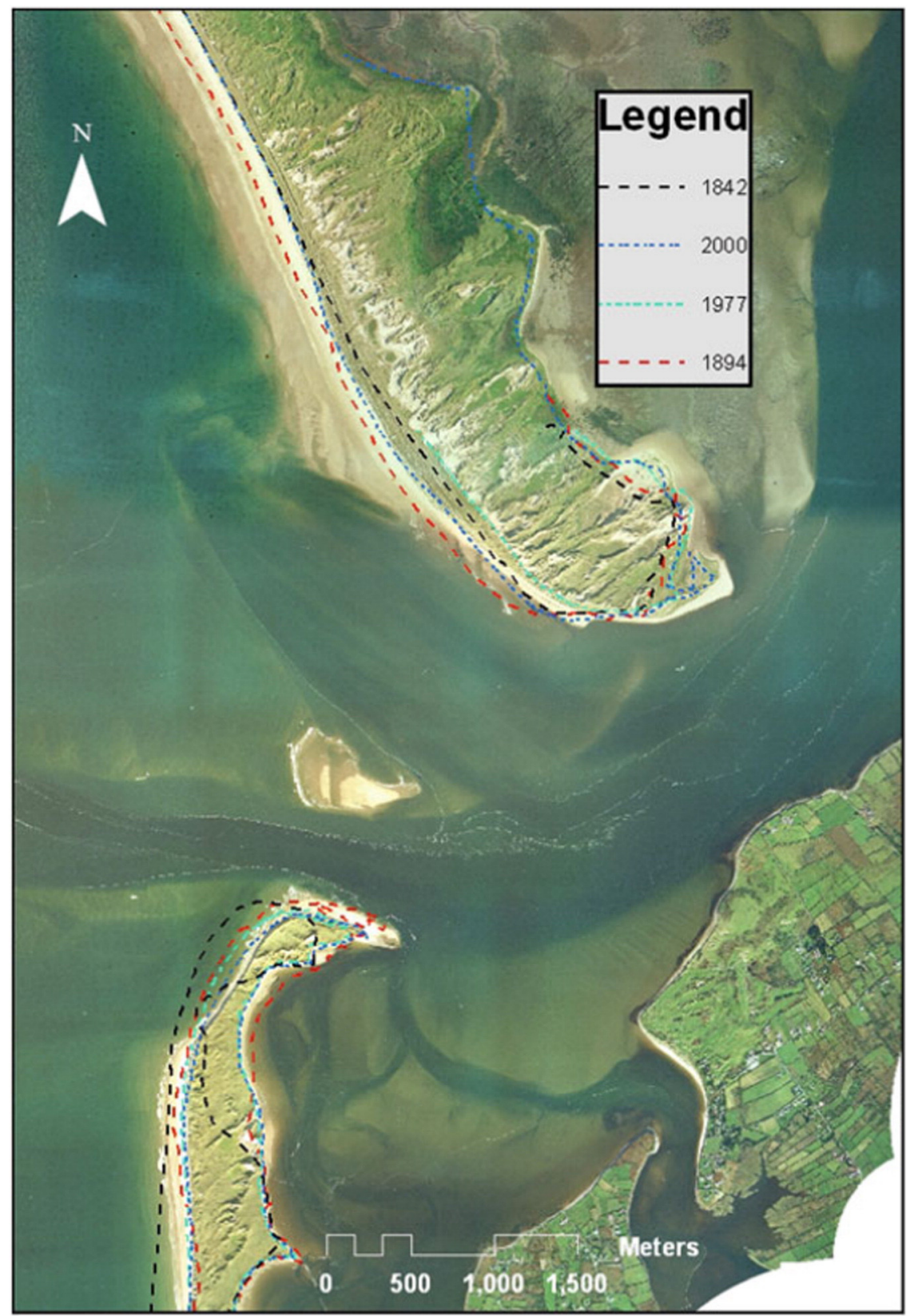

Fig. 8. Inch and Rossbehy spit shoreline evolution from OSI map aerial photographs and field survey data since 1842. (O'Shean and Murphy, 2013)

The building of circa $250 \mathrm{~m}$ of rip-rap embankment in 2009 (Fig. 1), to protect the coastal road and the northern junction of Inch with the mainland (costing more than $€ 4 \mathrm{M}$ ) shows the need to have integrated funding plans (the Local Authority had no immediate funding). Subsequently, annual wave erosion and storm impacts on the beach, road and tourism infrastructures at Rossbehy, particularly the impact of the December 2013-February 2014 storm surges, have cost more than $€ 1 \mathrm{M}$ in remedial measures alone (Fig. 1) see e.g. (KCC, 2009; Gault et al., 2011, O'Connor et al., 2010). These costs, in the context of very limited Local Authority coastal management budgets and the $3500 \mathrm{~km}$ of Ireland's 'soft' sedimentary coasts experiencing potentially similar problems make the situation not sustainable.

As coastal systems, these beach-dune-barriers are not subject to active control and management, except within the context of overall coastal planning policies, which recognise the sensitive and vulnerable nature of these environments (ECOPRO, 1996; Cooper and Pile, 2014).
However, established seasonal uses for animal pasture of these increasingly environmentally stressed dune areas continues.

Local community pressure persists for the development of the currently more stable northern end of Inch as a golf course and the further encouragement of beach tourism. Off-road vehicles and horse riding are using the dunes increasingly, together with walking and the wider impacts of people, establishing new track ways and causing extensive sand mobilisation and erosion. Vehicles also continue to be permitted general access at Inch to the beaches fronting the dunes, adding to the sand losses from the beach and dune systems. Whilst local bye-laws and coastal legislation exist to prohibit or control the extent of such activities, this is not enforced rigorously, in spite of the best efforts of the Local Authority beach wardens (Gault et al., 2011).

Understanding and developing projections of how these structures will respond to future changes in coastal boundary conditions will depend upon the continued monitoring of these environments linked to 
high resolution morpho-hydrodynamic modelling. The use of interventionist approaches in managing these systems, in view of a likely tendency towards their further degradation and eventual disintegration, could be classified within a low sustainability category.

\subsection{High sustainability practices}

The North Dublin Bay area lies north of Howth Head, east coast Ireland, and includes the seaside communities from Portmarnock to Rush, which have developed extensively as urban areas since the 1950s (Fig. 9). Coasts here contain comparable higher energy beach- and dune-barrier systems to those found at Inch and Rossbehy, together with estuarine environments (Mulrennan, 1990, 1993; Orford et al., 1997). The barriers are fronted similarly by wide, commonly $50-150 \mathrm{~m}$ width, fine sand beaches. The wave energy regime is characterised by southerly degrading swell waves and by waves generated internally under short fetches within the Irish Sea (Vijaykumar et al., 2006). Coastal erosion events are common under storm surges and the retreat of the dune-barriers has been a cause of concern and implementation of engineered protection measures for decades (Gault et al., 2007).

Schemes for dune stabilisation have been implemented at various times since the early 20th Century, using the planting of Marram and Lyme grasses, together with Sea Buckthorn (Hippophae rhamnoides) (Binggeli et al., 1992). These coastal areas support a number of prominent golf courses and form a major focus for recreation in the Dublin region. Activities include daily-based uses by the local population (e.g., walking, dog walking, horse riding, swimming), together with many wider recreational uses from weekend visitors and seasonal summer tourism. Further, the dunes themselves attract intensive use, apart from the specific golfing activities (Gault et al., 2007). They have also been encroached on for building since the 1920s, initially for temporary beach huts and holiday homes, but increasingly since the 1980s for more permanent residences. This building pressure has concentrated people's attention on coastal erosion, with storms post 2005 causing more than 5-10 m of dune loss in single events, and consequently increased calls by seaside residents for the building of fixed defence structures.

In response to this range of uses and development pressures the Local Authority has initiated a proactive policy of coastal management. This has covered a wide range of initiatives since the mid $2000 \mathrm{~s}$. The problems of sediment losses and the general nuisance created by beach vehicle access has been stopped, or reduced significantly. The open access dune areas, many of which had become overgrown by Sea Buckthorn have been cleared progressively and Marram grass planting schemes developed, together with the use of screens, brush-wood fencing and other bio-defence techniques. People's access to the beaches through the dune-barriers has increasingly become routed via fenced and corduroy-wood pathways (Fig. 9). Additionally, an along-coast walkway has been developed, where feasible, as part of a wider national and EU funded coastal tourism and heritage development (Gault et al. (2007).

The problems of coastal erosion continue, but are not being addressed through the implementation of high cost engineered defence structures. Beach levels and erosion monitoring schemes, involving local community participation where possible, are being practised. The local communities are also being involved in discussion on the issues of the long term cost and sustainability of traditional fixed coastal protection structures. Discussions have encouraged thinking in terms of alternative approaches, including structured coastal retreat, compensation for property loss and the use of low cost remedial protection techniques, where some defence measures become essential (Gault et al., 2007; Marchand et al., 2011). These approaches remain controversial locally, but are being initiated. Due to the comparatively lower cost and impact of these approaches, and particularly their reduced carbon footprint, this case can be considered an illustration of good adaptation in the face of future climatic changes.

\section{The Romanian case}

\subsection{Coastal description}

The Danube Delta coast has a total length of about $240 \mathrm{~km}$, divided between the Ukraine and Romania. The Romanian part of the Danube Delta coast is a stretch of $160 \mathrm{~km}$ of low-lying natural beaches generally consisting of fine sands brought by the Danube River and redistributed by waves and currents. The Danube delta coast morphology, sedimentology and recent dynamics have been extensively studied and described by a series of publications, see e.g. (Panin, 1996, 1998, 1999; Giosan et al., 1999; Ungureanu and Stanica, 2000; Bhattacharya and Giosan, 2003; Stanica et al., 2007, 2011; Stanica and Panin, 2009; Vespremeanu-Stroe et al., 2007; Dan et al., 2009, 2011).

The Danube Delta coast (Stanica et al., 2013) can be divided into three major coastal sedimentary cells that from North to South can be presented as (Fig. 10) Chilia (Kilia) sedimentary cell, Sulina - Sf. Gheorghe sedimentary cell and Zatoane-Midia Harbour sedimentary cell. The solid discharge that feds these cells has decreased to a half with a baseline prior to 1970 when the Iron Gate I ( $943 \mathrm{~km}$ upstream) and II (864 km upstream) were built in 1970 and 1983, respectively (Giosan et al., 2013).

The Chilia cell represents the coast in front of the Kilia secondary delta. Most of it is in the Ukraine and it includes also the state boundary between the Ukraine and Romania in Musura Lagoon (area with active sedimentation, which has been recently transformed from a bay into a lagoon). The southern boundary of this cell is impermeable, being

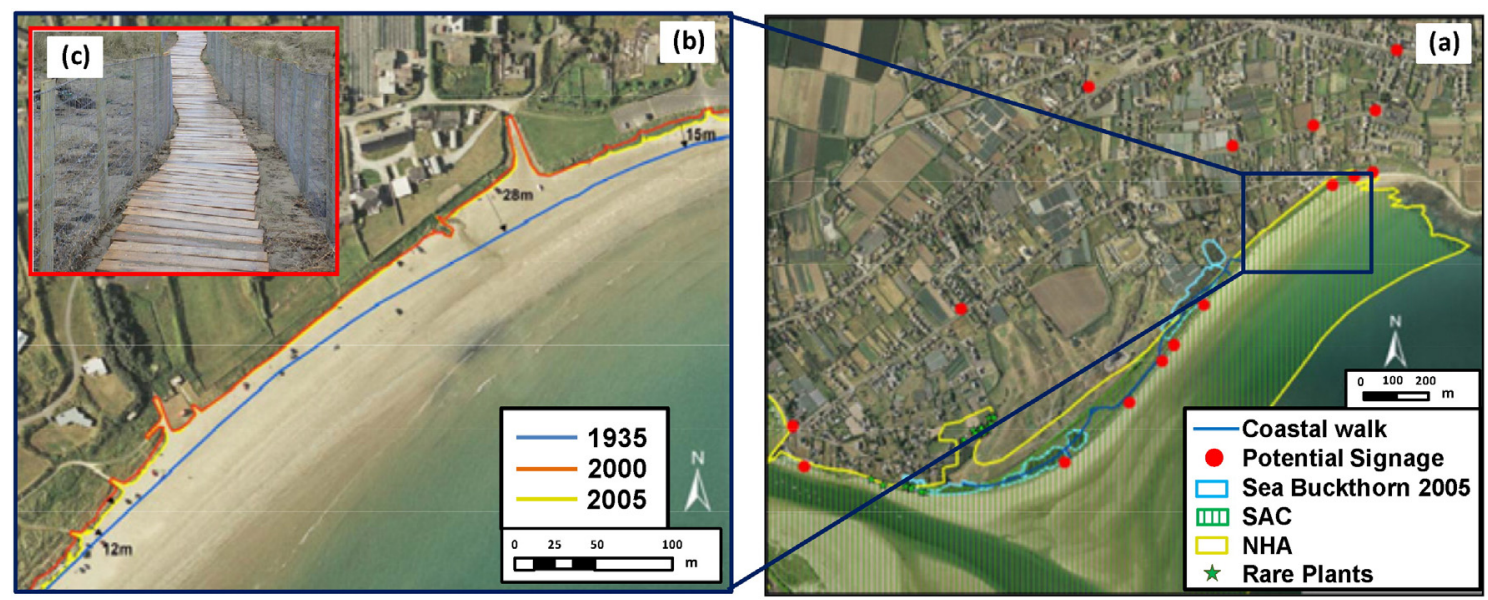

Fig. 9. Zonification of activities/interventions and coastline evolution at the Northern beaches of Dublin. 


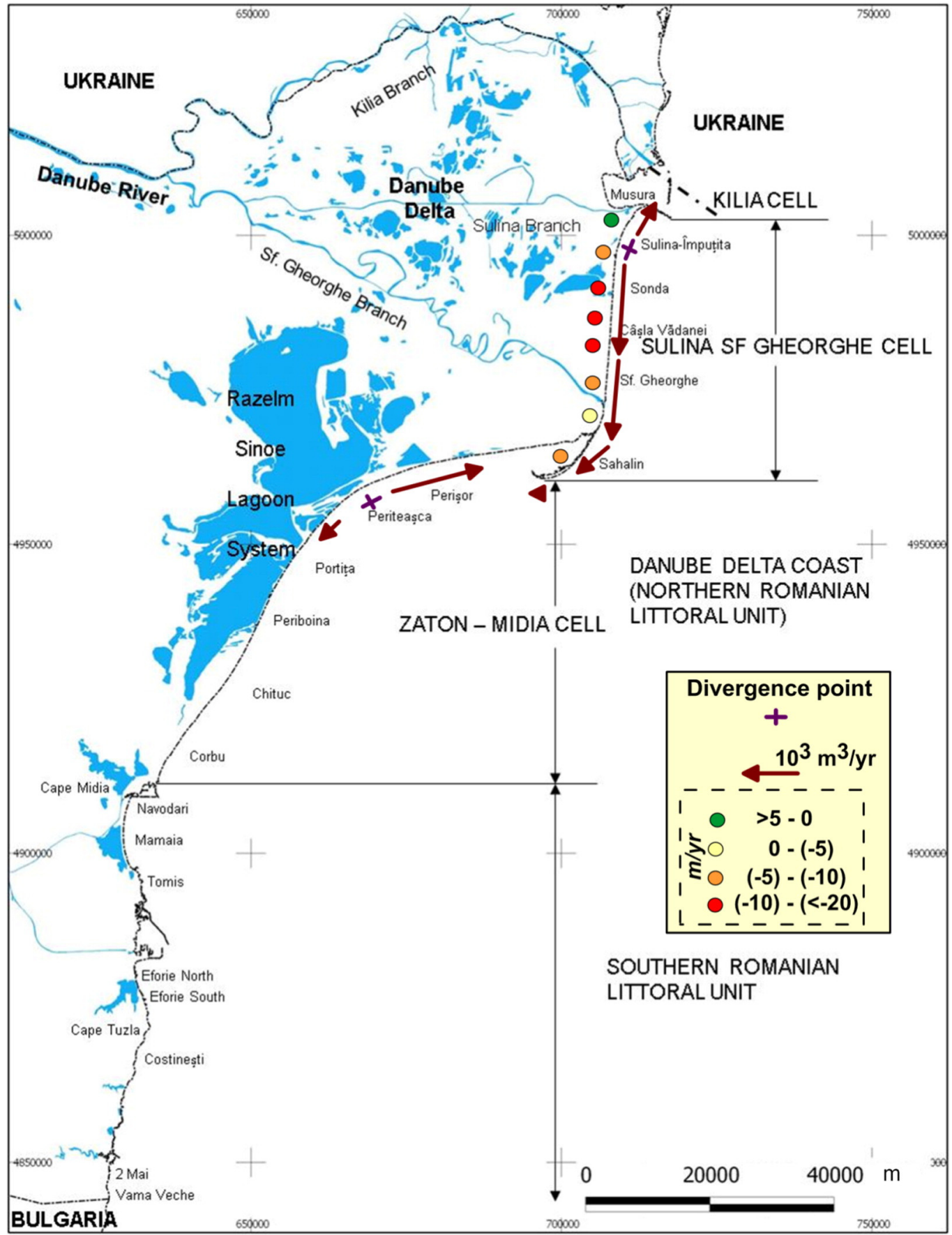

Fig. 10. Danube delta littoral cells, shoreline evolution and longshore sediment patterns.

marked by the Sulina Canal jetties. These were built to protect the waterway and ensure the safe navigation along Sulina, the middle branch of the Danube. These structures extend 8km offshore; they block sediment transported alongshore from the north and represent thus an impermeable boundary between the Kilia and Sulina - Sf. Gheorghe sedimentary cells.

The Sulina - Sf. Gheorghe sedimentary cell is about $60 \mathrm{~km}$ in length, where $34 \mathrm{~km}$ spans between the Danube mouths of Sulina and Sf. Gheorghe; whilst Sahalin Spit, at the southern part of the Sf. Gheorghe Danube mouth, covers the rest. The southern tip of Sahalin Spit is the southern cell boundary. The general longshore circulation pattern is from north to south, except for the northern section. Herein, the Sulina jetties generate an eddy-like current, which has reversed the longshore drift from south to north. Most sediment from this cell is Danube born material, with less than $10 \%$ of calcareous material derived from shell fragments. The southern cell boundary is permeable, some sediments being occasionally transported to the neighbouring sedimentary cell under specific conditions.

At the central part (spanning about $20 \mathrm{~km}$ ), the shoreline is rapidly eroding with rates ranging between 5 and $20 \mathrm{~m} / \mathrm{yr}$ (Giosan et al., 2013). The Zatoane-Midia Harbour sedimentary cell is about $100 \mathrm{~km}$ in length, mainly represented by the barrier beaches separating the Razelm-Sinoe Lagoon system from the Black Sea. There were three inlets of the lagoon system - Portita, Periboina and Edighiol, all engineered between 1970 and late 1980s. Subsequently Portita inlet was closed and developed for tourism, while the inlets Periboina and Edighiol have now lock systems meant to control the water circulation between the sea and the lagoon. Most sediments are Danube alluvia, 
many of these remobilized by erosion of previous littoral bars. There is a gradual southwards increase (up to about 50\%) in the calcareous fraction (sands from mollusc shell fragments). The last few kilometres of this coastal cell are shaped by the first cliff outcrops at Cape Midia, the headlands being separated by long pocket beaches. The northern jetty of Midia Harbour represents the southern limit of this cell. This jetty, built around 1980 has a length of $5 \mathrm{~km}$ and blocks sediment longshore transfer towards the south, the Bay of Mamaia and Constanta City and Harbour.

\subsection{Low sustainability practices}

Since the Danube Delta coast mostly remains in its natural state, with wild low lying sandy beaches, it is impossible to provide examples for bad practices at the scale of the entire coast. No implemented practices that have had a bad effect on the current coastal dynamics were ever meant to play a role for coastal protection against erosion, while the disastrous plans for so called coastal protection developed 2 decades ago have never been put in practice.

Nevertheless, the coastal navigation and harbour protection works from the northern and southern boundaries of the coast have completely altered the sediment dynamics. Sulina jetties in the North (extending $8 \mathrm{~km}$ offshore) and Midia Jetties (extending $5 \mathrm{~km}$ offshore) represent impermeable coastal cell boundaries and induce a strong disequilibrium on the longshore sediment transfer. The southern boundary (Midia jetties) has also played a role in decreasing the coastal area fed by the Danube-born alluvia. Before their construction, the Mamaia Bay beaches (now outside the study area, which is also Romania`s biggest tourist resort) consisted of Danube born fine sediments.

Sulina jetties have altered the longshore dynamics and a sand bar is still forming at the river mouth. For navigation purposes it has to be dredged annually, but the material is deposited offshoreward, outside the active zone, rather than being deployed at the erosive spots at the Sulina-St Gheorghe cell. More than $7 \mathrm{Mm}^{3}$ have been dredged from 1991 to 2007 (Stanica et al., 2011). There is also accretion just at the beginning of the same cell, with observed rates of 5-8 m/yr (Stanica and Panin, 2009).

The closure of the Portita Inlet in 1974, aimed at transforming Razelm Lagoon into a freshwater lake was achieved by a set of 4 groins, which have played a major role in the local disruption of coastal dynamics (Ungureanu and Stanica, 2000). The coastal stretch south of Portia has witnessed an increase of the rate of coastal erosion, being nowadays around $5 \mathrm{~m} / \mathrm{yr}$ (Vespremeanu-Stroe et al., 2007).

\subsection{High sustainability practices}

Based on available information we consider as best practice for the Danube Delta coast the present Master plan for the Protection against Erosion for the Romanian Littoral. This exhaustive coastal protection document has been developed between 2011-2012 by a consortium led by Halcrow Ltd., in cooperation with GeoEcoMar, NIRD Antipa, University of Bucharest and the Institute of Marine Sciences - CNR, Italy. The plan acknowledges the legal status of Nature Protected Site of the Danube Delta coast and the dedicated coastal protection plans take this status into account. The strategy for most of the coast is to leave the beaches in natural evolution, abiding to the principle "nature must deal with nature". The spatial planning of the Danube Delta Biosphere Reserve, including also the coastal zone, prevents development of new constructions in unbuilt areas. As an extra protection measure, a setback line has been implemented along the entire Romanian coast with a width of $150 \mathrm{~m}$ from the position of the shoreline during calm seas, as defined at the end of the years 2000, see e.g. (Sanò et al., 2011; Stanica et al., 2011). New setback line positions are to be reestablished periodically, in order to take into account future coastline positions.
This policy, which ensures space for natural processes to occur is supported by the fact that, except for 2 settlements and other 3 developed sites with restricted areas, along the Danube Delta coast there are only very few permanent buildings, generally belonging to fishermen associations. The natural occurrence of reed beds in the close vicinity of the shoreline play, in some areas, the role of "green protection". Other proposals (Stanica et al., 2011) have suggested redistributing sand from the available sand reservoirs to erosive spots. Part of the applied budget may also be used to smooth the coastline with punctual beach nourishments, with the aim of reducing topography induced longshore gradients (as proposed in the Llobregat Delta, Section 4).

To maintain the natural evolution for most of the coast, the Master plan has a different proposal for the beaches between the Sulina and Sf. Gheorghe mouths, which represent a different means of implementing the "nature with nature" policy. Since the Sulina jetties, which extend $8 \mathrm{~km}$ offshore (see description in previous paragraphs), have played a significant role in altering the sediment transport on this part of the coast, the Master plan suggests the need to develop a sediment by-pass system, which would maintain the jetties but help restore the natural circulation. Plans exist also for the local protection of the 2 passages built on the inlets connecting Sinoe Lagoon to the sea, which are essential for the environmental restoration of this lagoon. Sinoe Lagoon inlets were engineered in the 1980s, having thus had limited connections with the sea for about 2 decades, and the impact of these measures on the lagoon habitat has been significant. Therefore the need to restore and maintain water circulation has been acknowledged since the years 2000, when the inlets were left under free flow conditions.

Initiatives proposed for the Ebro Delta (Section 4) can also be applied to the Danube Delta (Rovira et al., 2014). Two strategic sand reservoirs can be found at the Sulina mouth $\left(0.42 \mathrm{Mm}^{3} / \mathrm{yr}\right)$ and the Musura bay (north of the Sulina jetties). In order to increase sediment trapping, some authors (Giosan et al., 2013) have proposed increased channelization and abandoning erosive deltaic lobes, which would provide a sediment budget for stabilizing other areas. They also remarked that drowning of paleo-sand ridge sets and turning them into barrier systems could provide transient protection to the inland deltaic plain.

\section{A shared roadmap. Integrated assessment (present and future landscape)}

The interventions described (Sections 4 to 6) span a representative vision of present and near future coastal interventions in a range of European coasts settings. The spatial scales and lifetime differ among them, but some commonalities can be extracted towards the design of a shared roadmap. Two complementary paradigms are proposed for that: the benefits of long-term planning, based on top-down strategies and the efficiency of short-term interventions, driven by bottom-up strategies.

Identifying flexibilities and rigidities constitutes the first step for designing a pro-active pathway to sustainability. An adaptive plan needs to have some solid foundations (rigidities) but with flexibility enough to ensure that it will be applicable for the changing demands from climate, society or other factors. Three layers can be envisioned for developing this plan: i) coastal archetype representing the physical substratum (Section 2), ii) climate factors incorporating climatic and event scales and iii) social factors providing policy criteria and access to funding (Section 3). The archetypes are the layer in which more rigidity exists because it is based on the geology, sediment budget and the constraints generated by existing or planned infrastructures.

Whilst the Danube Delta (Section 6) presents an almost pristine environment with littoral cells that span more than $50 \mathrm{~km}$, the Maresme coast (Section 4) has cells with lengths smaller than $2 \mathrm{~km}$ and a rigid backshore partly occupied by a railway and motorway used daily by Barcelona commuters. The costs of replacing/substituting these infrastructures limit the fan of possible adaptation options. As a consequence 
the coastal protection function gains importance because of such valuable assets and this raises the vulnerability level. Better infrastructure attracts population and the coastal fringe vulnerability augments in a feedback loop that, unless broken, will take risk to an unacceptable level in the near future under climate change.

A long-term plan requires setting up a reference baseline. In the near future (until 2040), SLR projections (Section 3) present similar values. At the second half of this century, however, the SLR gradient becomes sharper for the high-end scenario (RCP 8.5). A high-end scenario is preferred as a baseline because it is both plausible and conservative. Bereft of cheap energy and natural resources, the costs of adaptation and mitigation will increase throughout time and the transition towards a lowcarbon society will be difficult (Brown et al., 2013; Hinkel et al., 2014). Available resources may be allocated to further economic growth (with the possibility of reaching a dead-end at the short-term) or to a societal transition combining rigid and flexible elements. Choosing the first option would only be justified for lower RCPs, lowering adaptation costs (with respect to higher RCPs) at the second part of the century and resulting in savings that could be used for fostering economic growth.

Monitoring networks should provide the quantitative data required for a continuous reassessment of impacts and the effect of "responses". Dynamic pathways need such information for forecasting and verification (Haasnoot et al., 2013). This constitutes the basis for uncertainty reduction in the DPSIR chain, thus providing robustness in the decision making. Long time series such as the XIOM network (Bolanos et al., 2009) verifies model projections and sharpens the definition of the pathways, integrating processes and interactions that the models cannot reproduce.

Probabilistic projections can cope with some of the models' limitations. They can be introduced through combinations of perturbations in boundary/initial conditions and through multi-ensemble simulations (Wang et al., 2015). This probabilistic approach can serve for defining upper limits (Jevrejeva et al., 2014a) or bounding the uncertainty (Muis et al., 2015). Consistency among climatic co-factors and their dependencies also enhances robustness and it can be introduced with multivariate statistical methods such as Hierarchical Archimedean Copulae (Lin-Ye et al., 2015).

Local interventions for coastal sustainability are here clustered into two groups: working with nature (reed beds at the Danube Delta, restoration of dunes at Inch, overwash enhancement at Ebro Delta) and Transient Defence Measures (TDM), such as the fuse dune system at Llobregat Delta. The TDM method consists of coastal protection based on specific actions that should be deployed prior to extreme events. The interest in these interventions will grow in a changing climate because enhanced flooding and erosion due to SLR and increases in population will raise social and economic vulnerability (Section 4). TDM will become more competitive because they present lower costs and impacts than conventional engineering solutions and offer added flexibility based on local resources (Sanchez-Arcilla et al., 2015a). Such an approach, however, requires the support of an early warning system to predict the storm impact with enough advance time to deploy the TDM for the more vulnerable coastal sectors.

The cases of Rossbehy, Sahalin Spit and Trabucador bar present a dynamic behavior that can be improved through natural processes (working with Nature). These fragile environments are highly affected by extreme events (Dan et al., 2011; Gracia et al., 2013a; Williams et al., 2015). However, overwash episodes can lead to accretion (Ibáñez et al., 2014; Sanchez-arcilla et al., 2015b) that results beneficial for the mid to long term sediment budget. Long-term planning cannot include hard works at the spit boundaries that could block the longshore sediment fluxes and, thus, prevent the natural sedimentary feeding of these beaches (see Section 2). Limited artificial nourishment can be shaped with a natural plan/profile such as for instance forming the emerged part of a dune. That would provide a sediment buffer but would also limit overwash, requiring a careful balance to offset any adverse effects.
Local interventions for "urgent" short term problems are often in conflict with long term sustainability criteria and cannot be easily implemented by lack of a legal framework for "fast track" interventions (Gault et al., 2011). The deployment of a TDM can be forecasted $72 \mathrm{~h}$ prior to an extreme event and would require about $24 \mathrm{~h}$ to be built. Such short term decisions should always provide the flexibility needed to deal with coastal uncertainties and be shared with local stakeholders to facilitate the uptake of new solutions. This is now easier than a few years back due to the advent of more sophisticated tools for diagnosis and forecasting coastal impacts and interactions (Garcia-Leon et al., 2015; Gracia et al., 2014). Early warning systems fed by observational networks can forecast extreme events and associated coastal hazards (Sanchez-Arcilla et al., 2014). These tools would provide local communities with objective information that ensures the timely deployment of TDM or longer term proactive interventions. This would result in lower mitigation costs and $\mathrm{C}$ footprint (compared to conventional engineering solutions).

The adaptation pathway should also include a follow-up, to assess the efficiency of the proposed interventions and establish critical or tipping points in the development (Haasnoot et al., 2013). It is an essential requirement for an adaptation plan since only this information will allow a critical assessment of the positive and negative impacts of the intervention which together with its initial and maintenance costs should permit a continuous assessment of the long term consequences. The pathway should thus include an adjustment block, consisting of all interventions that maximise the benefit or mitigate the negative impact of past interventions. This adjustment should also incorporate a continuous monitoring such as for instance would be required by artificial nourishment or vegetation in the sense that part of the adjustment is the maintenance of those activities (Stanica et al., 2011). The pathway should finally include an educational component, to allow a proper interpretation of costs and benefits at the various time scales and thanks to that provide a structured input from stakeholders and the users of that coastal system.

\section{Conclusions}

The elusive concepts of sustainability and adaptation have been here considered starting form coastal functions such as tourism and protection for the hinterland. By interpreting littoral environments as providers of natural services we have shown the viability of applying the DPSIR framework for analysis at present and future time scales.

From the comparative analysis of these three cases it has been found that natural resilience is larger for more energetic coasts (Ireland) and lower for littorals with milder drivers (Romania). Vulnerability, however, is larger for more intense competition between uses and longer coastal tracts (e.g. Spain before the barriers were built). When assessing low and high sustainability practices there were important commonalities, linking unsustainability with short term (interventionist) approaches based on rigid barriers and limited duration nourishments. This was accompanied by the lack of an integrated management (in some cases such a plan existed bit was not implemented). The high sustainability practices relied on a more holistic assessment of resources (such as, for instance, sediment availability) including nearby coastal areas and river catchment basins. It also involved incremental interventions with regular monitoring and local community involvement. The more sustainable approach favoured "green" protection, strategic sediment reservoirs and the establishment of set-back lines within a planned realignment of the coastline.

The comparative analysis has also shown how the three studied pilots present a similar historic evolution, with cases experiencing a higher pressure of uses leading the way in achievements and mistakes. That suggests the need to learn from the comparison, since even the values of dredged materials and nourishments are similar (refer to the Romanian and the Spanish cases respectively). The more sustainable adaptation pathways should start from a master plan that addresses 
all coastal components and includes all relevant scales, in particular balancing short term against long term. The proposed interventions should, thus, go from reactive (present, low sustainability) to proactive (future, high sustainability), using "green" defences while limiting hard and soft (stone and sand base respectively) defences to the bounds imposed by available energy or funds. The role of strategic sand reservoirs, considering sand as a limited fossil resource for many countries, should be another requirement for coastal sustainability in the coming decades.

The need for downscaling the physical and socio-economic projections at the spatial scale considered have been illustrated for study cases in Romania, Ireland and Spain. This has allowed addressing coastal zone management and adaptation in terms of coastal typologies (archetypes) that can be representative of other coastal tracts therefore allowing the exportation of the proposed approach to other coastal systems. The selection of robust variables for the projection, such as mean sea level and waves for the physical component and population density for the socio-economic component, has led to identifying sustainable and non-sustainable practices for the studied transects. Low sustainability has been associated with rigidization and short term views. Rigidization means working against natural processes and short term means a doubtful or unsustainable behaviour at longer time scales. High sustainability has been associated to building with Nature or short-long term compatibility. Using natural processes such as vegetation, or smart nourishment operations, has allowed discuss on of which are the dominant processes in optimizing coastal investment planning.

The compatibility between short and long term scales/processes has been illustrated with the flexible solution provided by transient defence measures, another way of illustrating the concept of partial barriers that only act when the energy level of meteorological and oceanographic drivers require it. The sequential set of actions that result, adapted for a given coastal archetype and explicitly considering a time and space scale, has been termed adaptation pathway. Such a combination aims to achieve efficiency in cost at short (initial construction) and medium/long term (maintenance and impact mitigation) which will result in sustainability from the standpoint of policy, economy and societal perception. Adaptation pathways, combining rigid and flexible elements and supplemented by an early warning system with suitable monitoring, should allow a permanent control of the coastal system, indicating the intervals for intervention and permitting a continuous reassessment of the proposed actions. The end result should be a more sustainable management of the coastal zone under present and future climates.

\section{Acknowledgements}

This paper has been partly supported by the EU research projects DANCERS (FP7-603805), RISES-AM- (FP7-ENV-693396) and iCoast (GA ECHO/SUB/2013/661009). The authors also want to acknowledge the Spanish research project PLAN-WAVE (CTM2013-45141-R, MINECO - FEDER co-fund). The second author also acknowledges the PhD scholarship from the Government of Catalonia (DGR FI-AGAUR14, Generalitat de Catalunya). Finally we would like to thank two anonymous reviewers for their valuable comments and suggestions that have allowed improving this paper.

\section{References}

Alfieri, L., Burek, P., Feyen, L., Forzieri, G., 2015. Global warming increases the frequency of river floods in Europe. Hydrol. Earth Syst. Sci. 19, 2247-2260.

Bhattacharya, J.P., Giosan, L., 2003. Wave-influenced deltas: geomorphic implications for facies reconstructions. Sedimentology.

Binggeli, P., Eakin, M., Macfadyen, A., Power, J., McConell, J., 1992. Impact of the alien sea buckthorn (Hippophae rhamnoides L.) on sand dune ecosystems in Ireland. In: Carter, R.W.G., Curtis, T.G.F., Sheehy-Skeffington, M.J. (Eds.), Coastal Dunes. Geomorphology, Ecology and Management. Balkema, Rotterdam, pp. 325-337.
Bolanos, R., Jorda, G., Cateura, J., Lopez, J., Puigdefabregas, J., Gomez, J., Espino, M., 2009. The XIOM: 20 years of a regional coastal observatory in the Spanish Catalan coast. J. Mar. Syst. 77, 237-260.

Brown, S., Nicholls, R.J., 2015. Subsidence and human influences in mega deltas: the case of the Ganges-Brahmaputra-Meghna. Sci. Total Environ. 527-528, 362-374.

Brown, S., Nicholls, R., Lowe, J., Hinkel, J., 2013. Spatial variations of sea-level rise and impacts: an application of DIVA. Clim. Chang. 1-14.

Carter, R.W.G., Woodroffe, C.D., 1994. Coastal Evolution: Late Quaternary Shoreline Morphodynamics. Cambridge University Press.

Casas-Prat, M., Sierra, J.P., 2013. Projected future wave climate in the NW Mediterranean Sea. J. Geophys. Res. Oceans 118, 3548-3568.

CEDEX, 2013. Estudio de la dinámica litoral, defensa y propuesta de mejora en las playas con problemas: Estrategia de actuación en el Maresme. Centro de Estudios y Experimentación de Obras Públicas.

Church, J.A., Clark, P.U., Cazenave, A., Gregory, J.M., Jevrejeva, S., Levermann, A., Merrifield, M.A., Milne, G.A., Nerem, R.S., Nunn, P.D., Payne, A.J., Pfeffer, W.T., Stammer, D., Unnikrishnan, A.S., 2013. Sea Level Change. In: Stocker, T.F., Qin, D., Plattner, G.K., Tignor, M., Allen, S.K., Boschung, J., Nauels, A., Xia, Y., Bex, V., Midgley, P.M. (Eds.), Climate Change 2013: The Physical Science Basis. Contribution of Working Group I to the Fifth Assessment Report of the Intergovernmental Panel on Climate Change. Cambridge University Press, Cambridge, United Kingdom and New York, NY, USA, pp. 1137-1216.

CIIRC, 2010. Estat de la zona costanera a Catalunya. (Departament de Pol\{'i\}tica Territorial i Obres Publiques) Generalitat de Catalunya.

Conte, D., Lionello, P., 2013. Characteristics of large positive and negative surges in the Mediterranean Sea and their attenuation in future climate scenarios. Glob. Planet. Chang. 111, 159-173.

Cooper, J.A.G., Cummins, V., 2009. Coastal management in Northwest Europe. Elsevier, Amsterdam.

Cooper, J.A.G., Pile, J., 2014. The adaptation-resistance spectrum: a classification of contemporary adaptation approaches to climate-related coastal change. Ocean Coast. Manag. 94, 90-98.

Cooper, J.A.G., Pilkey, O.H., 2012. Pitfalls of Shoreline Stabilization: Selected Case Studies. Springer, London.

Dan, S., Stive, M.J.F., Walstra, D.-J.R., Panin, N., 2009. Wave climate, coastal sediment budget and shoreline changes for the Danube Delta. Mar. Geol. 262, 39-49.

Dan, S., Walstra, D.-J.R., Stive, M.J.F., Panin, N., 2011. Processes controlling the development of a river mouth spit. Mar. Geol. 280, 116-129.

Delaney, C.A., Devoy, R.J.N., Jennings, S.C., 2012. Mid to late Holocene relative sea-level and sedimentary changes in southwest Ireland. In: Duffy, P.J., Nolan, W. (Eds.), At the Anvil. Geography Publications, Dublin, pp. 697-746.

Devoy, R.J.N., 1987. Sea Surface Studies: A Global View. Croom Held and Chapman Hall, London.

Devoy, R.J.N., 1992. Questions of coastal protection and the human response to sea-level rise in Ireland and Britain. Ir. Geogr. 25, 1-22.

Devoy, R.J.N., 2008. Coastal vulnerability and the implications of sea-level rise for Ireland. J. Coast. Res. 325-341.

Devoy, R.J.N., 2009. Iveragh coasts and mountains. In: Crowley, J., Sheehan, J. (Eds.), The Iveragh Peninsula: A Cultural Atlas of the Ring of Kerry. Cork University Press, pp. 33-44.

Devoy, R.J.N., 2015a. The development and management of the Dingle bay spit-barriers of soutwest Ireland. In: Randazzo, G., Jackson, D.W.T., Cooper, J.A.G. (Eds.), Sand and Gravel Spits. Springer, pp. 139-180.

Devoy, R.J.N., 2015b. Sea-level rise: causes, impacts and scenarios for change. In: Sherman, D., Ellis, J. (Eds.), Coastal and Marine Hazards, Risks and Disasters. Elsevier, Amsterdam, pp. 197-242.

Devoy, R.J.N., Delaney, C., Carter, R.W.G., Jennings, S.C., 1996. Coastal stratigraphies as indicators of environmental changes upon European Atlantic Coasts in the Late Holocene. J. Coast. Res. 12, 564-588.

Duffy, M.J., Devoy, R.J.N., 1999. Contemporary process controls on the evolution of sedimentary coasts under low to high energy regimes: western Ireland. Geol. Mijnb. 77. 33-49.

ECOPRO, 1996. Environmentally Friendly Coastal Protection (ECOPRO): code of practice. Department of Marine and Natural Resources (Dublin), Forbait, and the Department of the Environment (Northern Ireland). Government Publications, Dublin.

EEA, 1995. Europe's Environment: The Dobris Assessment. European Environmental Agency, Copenhagen.

EEA, 2014. European Environmental Agency Report, Global and European Sea-level Rise (CLIM 012) - Assessment Published Sept. 2014. http://www.eea.europa.eu/dataand-maps/indicators/sea-level-rise-2/assessment.

Eurosion, 2004. Living with Coastal Erosion in Europe: sediment and space for sustainability. Part I: Major Findings and Policy Recommendations of the EUROSION Project. Office for Official Publications of the European Communities, Luxembourg.

Fang, J., Sun, S., Shi, P., Wang, J.a., 2014. Assessment and mapping of potential storm surge impacts on global population and economy. Int. J. Disaster Risk Sci. 5, 323-331.

Garcia-Leon, M., Gracia, V., Robichaux, L., Kroger, A., Gault, J., Sanchez-Arcilla, A., 2015. Evaluation of Transient Defence Measures Against Storms, Coastal Sediments 2015. World Scientific.

Gault, J., Morrissey, C., Devoy, R.J.N., 2007. Dune Protection Plan for the Fingal Coast, Co. Dublin. The Coastal and Marine Research Centre, UCC and Fingal County Council, Dublin.

Gault, J., O'Hagan, A.M., Cummins, V., Murphy, J., Vial, T., 2011. Erosion management in Inch beach, South West Ireland. Ocean Coast. Manag. 54, 930-942.

Giosan, L., Bokuniewicz, H., Panin, N., Postolache, I., 1999. Longshore sediment transport pattern along the Romanian Danube Delta coast. J. Coast. Res. 4, 859-871.

Giosan, L., Stefan, C., Filip, F., Deng, B., 2013. Maintenance of large deltas through channelization: nature vs. humans in the Danube delta. Anthropocene 1, 35-45. 
Gracia, V., Garcia, M., Grifoll, M., Sanchez-Arcilla, A., 2013a. Breaching of a barrier under extreme events. The role of morphodynamic simulations. J. Coast. Res. 65, 951-956.

Gracia, V., Garcia-Leon, M., Sanchez-arcilla, A., Gault, J., Oller, P., Fernández, J., Sairouni, A. Cristofori, E., Toldrà, R., 2014. A new generation of early warning systems for coastal risk: the iCoast project. International Conference on Coastal Engineering, pp. 1-8.

Gracia, V., Sanchez-Arcilla, A., Anfuso, G., 2013b. Spain. In: Pranzini, E., Williams, A. (Eds.), Coastal Erosion and Protection in Europe. Routledge, Oxon, pp. 254-274.

Gray, S.R.J., Gagnon, A.S., Gray, S.A., O'Dwyer, B., O'Mahony, C., Muir, D., Devoy, R.J.N., Falaleeva, M., Gault, J., 2014. Are coastal managers detecting the problem? Assessing stakeholder perception of climate vulnerability using Fuzzy Cognitive Mapping. Ocean Coast. Manag. 94, 74-89.

Haasnoot, M., Kwakkel, J.H., Walker, W.E., ter Maat, J., 2013. Dynamic adaptive policy pathways: a method for crafting robust decisions for a deeply uncertain world. Glob. Environ. Chang. 23, 485-498.

Hamm, L., Capobianco, M., Dette, H.H., Lechuga, A., Spanhoff, R., Stive, M.J.F., 2002. A summary of European experience with shore nourishment. Coast. Eng. 47, 237-264.

Hanson, H., Brampton, A., Capobianco, M., Dette, H., Hamm, L., Laustrup, A., Lechuga, A. Spanhoff, R., 2002. Beach nourishment project, practices and objectives: AN European overview. Coast. Eng. 47.

Harley, M.D., Ciavola, P., 2013. Managing local coastal inundation risk using real-time forecasts and artificial dune placements. Coast. Eng. 77, 77-90.

Hinkel, J., Lincke, D., Vafeidis, A.T., Perrette, M., Nicholls, R.J., Tol, R.S.J., Marzeion, B. Fettweis, X., Cezar, I., Levermann, A., 2014. Coastal flood damage and adaptation costs under 21st century sea-level rise. Proc. Natl. Acad. Sci. 111, 3292-3297.

Hinkel, J., Nicholls, R.J., Tol, R., Wang, Z.B., Hamilton, J.M., Boot, G., Vafeidis, A.T., McFadden, L., Ganopolski, A., Klein, R.J.T., 2013. A global analysis of erosion of sandy beaches and sea-level rise: an application of DIVA. Glob. Planet. Chang. 111, 150-158.

Ibàñez, C., Canicio, A., Day, J., Curcó, A., 1997. Morphologic development, relative sea level rise and sustainable management of water and sediment in the Ebre Delta, Spain. J. Coast. Conserv. 3, 191-202.

Ibáñez, C., Day, J.W., Reyes, E., 2014. The response of deltas to sea-level rise: natural mechanisms and management options to adapt to high-end scenarios. Ecol. Eng. 65, 122-130.

Ibáñez, C., Sharpe, P.J., Day, J.W., Day, J.N., Prat, N., 2010. Vertical accretion and relative sea level rise in the Ebro Delta Wetlands (Catalonia, Spain). Wetlands 979-988

IIASA, 2012. IIASA (International Institute for Applied Systems Analysis) 2012 SSP Database (version 0.93). https://secure.iiasa.ac.at/web-apps/ene/SspDb/dsd?Action= htmlpage\&page $=$ about.

IPCC, 2013. Climate Change 2013: The Physical Science Basis. Contribution of Working Group I to the Fifth Assessment Report of the Intergovernmental Panel on Climate Change. Cambridge University Press, Cambridge, United Kingdom and New York, NY, USA.

IPCC, 2014. In: Field, C.B., Barros, V.R., Dokken, D.J., Mach, K.J., Mastrandrea, M.D., Bilir, T.E., Chatterjee, M., Ebi, K.L., Estrada, Y.O., Genova, R.C., Girma, B., Kissel, E.S., Levy, A.N., MacCracken, S., Mastrandrea, P.R., White, L.L. (Eds.), Climate Change 2014: Impacts, Adaptation, and Vulnerability. Part A: Global and Sectoral Aspects. Contribution of Working Group II to the Fifth Assessment Report of the Intergovernmental Panel on Climate Change. Cambridge University Press, Cambridge, United Kingdom and New York, NY, USA.

Jenkins, G.J., Murphy, J.M., Sexton, D.M.H., Lowe, J.A., Kilsby, C.G., 2009. UK Climate Projections: Briefing Report (and 2010 Update). Met Office Hadley Centre, Exeter, United Kingdom.

Jevrejeva, S., Grinsted, A., Moore, J.C., 2014a. Upper limit for sea level projections by 2100. Environ. Res. Lett. 9, 104008.

Jevrejeva, S., Moore, J.C., Grinsted, A., Matthews, A., Spada, G., 2014b. Trends and acceleration in global and regional sea levels since 1807. Glob. Planet. Chang. 113, 11-22.

Jimenez, J.A., Gracia, V., Valdemoro, H.I., Mendoza, E.T., Sanchez-Arcilla, A., 2011. Managing erosion-induced problems in NW Mediterranean urban beaches. Ocean Coast. Manag. 54, 907-918.

Kandrot, S., Devoy, R.J.N., Cawkwell, F., Gault, J., 2014. Monitoring and Modelling Micro- to Meso-scale Dune-barrier Behaviour Using Terrestrial Laser Scanning, Irish Geomorphology Group First Annual Papers and Workshop Meeting. Department of Geography, Trinity College, Dublin.

KCC, 2001. Development plan review. KCC Review Issues Document 10/12/01-5/02/02 Tralee. Kerry County Council.

KCC, 2009. December Ordinary Meeting Minutes. Kerry County Council, Tralee, p. 58.

Kristensen, P., 2004. The DPSIR Framework, Workshop on a Comprehensive/Detailed Assessmentof the Vulnerability of Water Resources to Environmental Change in Africa using River Basin Approach. National Research Institute (Denmark), Nairobi,Kenya.

LIM/UPC, 2014. Proposal for the Predesign of Solutions for Coastal Stabilisation at the Gava Beaches. LIM/UPC (Maritime Engineering Laboratory - Polytechnic University of Catalonia), p. 173

Lin-Ye, J., Garcia, M., Gracia, V., Sanchez-arcilla, A., 2015. A multivariate model of NW Mediterranean extreme events at present and future climate: hydrodynamics, energy and duration. Conference of the International Association for Mathematical Geosciences, pp. 1-9.

Lionello, P., Boldrin, U., Giorgi, F., 2008. Future changes in cyclone climatology over Europe as inferred from a regional climate simulation. Clim. Dyn. 30, 657-671.

Lowe, J.A., Woodworth, P.L., Knutson, T., McDonald, R.E., McInnes, K.L., Woth, K., von Storch, H., Wolf, J., Swail, V., Bernier, N.B., Gulev, S., Horsburgh, K.J., Unnikrishnan, A.S., Hunter, J.R., Weisse, R., 2010. Past and Future Changes in Extreme Sea Levels and Waves, Understanding Sea-Level Rise and Variability. Wiley-Blackwell, pp. 326-375.

Malvarez, G., Pollard, J., Dominguez, R., 2000. Origins, management and measurement of stress on the coast of Southern Spain. Coast. Manag. 215-234.
Marchand, M., Sanchez-Arcilla, A., Ferreira, M., Gault, J., Jimenez, J.A., Markovic, M. Mulder, J., 2011. Concepts and science for coastal erosion management - an introduction to the CONSCIENCE framework. Ocean Coast. Manag. 12, 859-866.

Masselink, G., Hughes, M.G., Knight, J., 2011. Coastal Processes and Geomorphology. Hodder Education, London.

Menéndez, M., Woodworth, P.L., 2010. Changes in extreme high water levels based on a quasi-global tide-gauge data set. J. Geophys. Res. Oceans 115 (n/a-n/a).

Muis, S., Güneralp, B., Jongman, B., Aerts, J.C.J.H., Ward, P.J., 2015. Flood risk and adaptation strategies under climate change and urban expansion: a probabilistic analysis using global data. Sci. Total Environ. 538, 445-457.

Mulrennan, M.E., 1990. The Geomorphic Development of the Barrier-Beach complexes of North County Dublin Coastline. University College Dublin.

Mulrennan, M.E., 1993. Changes since the nineteenth Century to the Estuary Barrier Complexes of North County Dublin. Ir. Geogr. 1, 1-13.

Neumann, B., Vafeidis, A.T., Zimmermann, J., Nicholls, R.J., 2015. Future coastal population growth and exposure to sea-level rise and coastal flooding - a global assessment. PLoS ONE 10, e0118571.

Nissen, K., Leckebusch, G., Pinto, J., Ulbrich, U., 2014. Mediterranean cyclones and windstorms in a changing climate. Reg. Environ. Chang. 14, 1873-1890.

NPWS, 2011. Castlemaine Harbour SAC (Site Code 343): Conservation Objectives Supporting Document, Coastal Habitats. National Parks and Wildlife Service, Dublin.

O'Connor, M.C., McKenna, J., Cooper, J.A.G., 2010. Coastal issues and conflicts in North West Europe: a comparative analysis. Ocean Coast. Manag. 53, 727-737.

O’Neill, B., Kriegler, E., Riahi, K., Ebi, K., Hallegatte, S., Carter, T., Mathur, R., van Vuuren, D. 2014. A new scenario framework for climate change research: the concept of shared socioeconomic pathways. Clim. Chang. 122, 387-400.

OECD, 1993. OECD Core Set of Indicators for Environmental Performance Reviews Organization for Economic Cooperation and Development. OECD, Paris, France.

Orford, J.D., Carter, R.W.G., Jennings, S.C., 1996. Control domains and morphologica phases in gravel-dominated coastal barriers of Nova Scotia. J. Coast. Res. 12 589-604.

Orford, J.D., Cooper, J.A.G., Smith, B., 1997. LOICZ: the human factor as an influence on the Irish coast. In: Sweeney, J. (Ed.), Global Change and the Environment. Royal Irish Academy, pp. 88-107.

O'Shea, M., Murphy, J., 2013. Predicting and monitoring the evolution of a coastal barrier dune system postbreaching. J. Coast. Res. 38-50.

Pacheco, A., Carrasco, A.R., Vila-Concejo, A., Ferreira, O., Dias, J.A., 2006. A coastal management program for channels located in back barrier systems. Ocean Coast. Manag. 119-143.

Panin, N., 1996. Impact of global changes on geoenvironmental and coastal zone state of the Black Sea. Geo-Eco-Marina, pp. 7-23.

Panin, N., 1998. Danube Delta: Geology, Sedimentology, Evolution. Association des Sedimentologistes Francais, Paris (65 pp.).

Panin, N., 1999. Global changes, sea level rise and the Danube delta: risks and responses. Geo-Eco-Marina.

Planton, S., Lionello, P., Artale, V., Aznar, R., Carrillo, A., Colin, J., Congedi, L., Dubois C., Elizalde, A., Gualdi, S., Hertig, E., Jacobeit, J., Jordà, G., Li, L., Mariotti, A. Piani, C., Ruti, P., Sanchez-Gomez, E., Sannino, G., Sevault, F., Somot, S. Tsimplis, M., 2012. 8 - the climate of the Mediterranean Region in future climate projections. In: Lionello, P. (Ed.), The Climate of the Mediterranean Region. Elsevier, Oxford, pp. 449-502.

Roelvink, J.A., Reniers, A.J.H.M., Dongeren, A.R.V., van Thiel de Vries, J.S.M., McCall, R. Lescinski, J., 2009. Modeling storm impacts on beaches, dunes and barrier islands. Coast. Eng. 56.

Rovira, A., Ballinger, R., Ibáñez, C., Parker, P., Dominguez, M.D., Simon, X., Lewandowski, A., Hochfeld, B., Tudor, M., Vernaeve, L., 2014. Sediment imbalances and flooding risk in European deltas and estuaries. J. Soils Sediments 14, 1493-1512.

Sanchez-Arcilla, A., Garcia, M., Gracia, V., 2015a. Sustainability of artificial coasts: the Barcelona coast case. Coastal Zones: Solutions for the 21st Century. Elsevier, pp. $163-182$.

Sanchez-Arcilla, A., Garcia-Leon, M., Gracia, V., 2014. Hydro-morphodynamic modelling in Mediterranean storms - errors and uncertainties under sharp gradients. Nat. Hazards Earth Syst. Sci. 14, 2993-3004.

Sanchez-arcilla, A., Gracia, V., Garcia-Leon, M., Jimenez, J.A., Caceres, I., Valdemoro, H. 2015b. Natural accretion mechanisms: the role in future coastal sustainability. Coastal Sediments. World Scientific Publishing, pp. 1-14.

Sanò, M., Jiménez, J.A., Medina, R., Stanica, A., Sanchez-Arcilla, A., Trumbic, I., 2011. The role of coastal setbacks in the context of coastal erosion and climate change. Ocean Coast. Manag. 54, 943-950.

Stanica, A., Panin, N., 2009. Present evolution and future predictions for the deltaic coasta zone between the Sulina and Sf. Gheorghe Danube river mouths (Romania). Geomorphology 107, 41-46.

Stanica, A., Dan, S., Gheorghe, U.V., 2007. Coastal changes at the Sulina mouth of the Danube River as a result of human activities. Mar. Pollut. Bull. 55, 555-563.

Stanica, A., Dan, S., Jiménez, J.A., Ungureanu, G.V., 2011. Dealing with erosion along the Danube Delta coast. The CONSCIENCE experience towards a sustainable coastline management. Ocean Coast. Manag. 54, 898-906.

Stanica, A., Panin, N., Caraivan, G., 2013. Romania. In: Pranzini, E., Williams, A. (Eds.) Coastal Erosion and Protection in Europe. Routledge, Oxon, pp. 397-412.

Syvitski, J.P.M., Kettner, A.J., Overeem, I., Hutton, E.W.H., Hannon, M.T., Brakenridge, G.R. Day, J., Vorosmarty, C., Saito, Y., Giosan, L., Nicholls, R.J., 2009. Sinking deltas due to human activities. Nat Geosci. 681-686.

Tsimplis, M.N., Josey, S.A., Rixen, M., Stanev, E.V., 2004. On the forcing of sea level in the Black Sea. J. Geophys. Res. Oceans 109 (n/a-n/a).

Ungureanu, G.V., Stanica, A., 2000. Impact of human activities on the evolution of the Romanian Black Sea Beaches. Lakes Reserv. Res. Manag. 111-115. 
Valchev, N.N., Trifonova, E.V., Andreeva, N.K., 2012. Past and recent trends in the western Black Sea storminess. Nat. Hazards Earth Syst. Sci. 12, 961-977.

Vespremeanu-Stroe, A.F.C., Tatui, F., Giosan, L., 2007. Multi-decadal evolution of the North Atlantic oscillation: influences on the dynamics of the Danube Delta shoreline. J. Coast. Res. 157-162

Vijaykumar, N.L., Devoy, R.J.N., Gault, J., Cronin, K., Arcilan, A., 2006. The modelling of wind and waves for the Irish shelf seas: a forty year hindcast wind and wave atlas for Ireland. International Meeting of Coastal Science, Littoral, 2006, 18-20 September. Gdansk University of Technology, Poland.

Viles, H., Spencer, T., 1995. Coastal Problems: Geomorphology, Ecology and Society at the Coast. Edward Arnold, London (350 pp.).
Wang, X.L., Feng, Y., Swail, V.R., 2014. Changes in global ocean wave heights as projected using multimodel CMIP5 simulations. Geophys. Res. Lett.

Wang, X.L., Feng, Y., Swail, V.R., 2015. Climate change signal and uncertainty in CMIP5based projections of global ocean surface wave heights. J. Geophys. Res. Oceans 120, 3859-3871.

Williams, J.J., Esteves, L.S., Rochford, L.A., 2015. Modelling storm responses on a highenergy coastline with XBeach. Model. Earth Syst. Environ. 1.

Woodroffe, C.A., 2002. Coasts: Form, Processes and Evolution. Cambridge University Press. 